\title{
Understanding the drivers of international performance for born global firms: an integrated perspective
}

Article

Accepted Version

Creative Commons: Attribution-Noncommercial-No Derivative Works 4.0

Gerschewski, S., Rose, E. L. and Lindsay, V. J. (2015) Understanding the drivers of international performance for born global firms: an integrated perspective. Journal of World Business, 50 (3). pp. 558-575. ISSN 1090-9516 doi: https://doi.org/10.1016/j.jwb.2014.09.001 Available at https://centaur.reading.ac.uk/74988/

It is advisable to refer to the publisher's version if you intend to cite from the work. See Guidance on citing.

To link to this article DOI: http://dx.doi.org/10.1016/j.jwb.2014.09.001

Publisher: Elsevier

All outputs in CentAUR are protected by Intellectual Property Rights law, including copyright law. Copyright and IPR is retained by the creators or other copyright holders. Terms and conditions for use of this material are defined in the End User Agreement.

www.reading.ac.uk/centaur 
Central Archive at the University of Reading

Reading's research outputs online 


\title{
Understanding the drivers of international performance for born global firms: An integrated perspective
}

\author{
Stephan Gerschewski ${ }^{\mathrm{a}, *}$, Elizabeth L. Rose ${ }^{\mathrm{b}, \mathrm{c}, 1}$, Valerie J. Lindsay ${ }^{\mathrm{d}, 2}$ \\ a Hannam University, Linton Global College, Department of Global Business, 70 Hannam-ro, Daedeok-gu, Daejeon 306-791, Republic of Korea \\ ${ }^{\mathrm{b}}$ University of Otago, PO Box 56, Dunedin 9054, New Zealand \\ ${ }^{\mathrm{c}}$ Aalto University School of Business, PO Box 21230, FI-00076 Aalto, Finland \\ ${ }^{\mathrm{d}}$ University of Wollongong in Dubai, PO Box 20183, Dubai, United Arab Emirates
}

\section{A R T I C L E I N F O}

\section{Keywords:}

Born global firm

International performance

Internationalisation

International entrepreneurship

Mixed methods

SME

\begin{abstract}
A B S T R A C T
Grounded in the resource-based view of the firm and the network perspective on internationalisation, we develop and test a model of early performance for born global firms. We employ a mixed-methods approach, combining exploratory interviews and survey data from 310 Australian and New Zealand companies. Our results suggest that international entrepreneurial orientation, focus on product/service quality, and competitor orientation are critical drivers of international performance for born globals. The key contributions of the study are the development of an integrated performance model for born global firms, using a nuanced operationalisation of performance, and an empirical comparison between born globals and traditionally internationalising firms.
\end{abstract}

(c) 2014 Elsevier Inc. All rights reserved.

\section{Introduction}

The past two decades have witnessed the emergence of early and rapidly internationalising firms as an important phenomenon (e.g., Knight \& Cavusgil, 1996; Oviatt \& McDougall, 1994). Growing interest in the internationalisation behaviour of these dynamic, "born global" 3 firms has driven a new research stream international entrepreneurship (IE) - which combines the international business and the entrepreneurship literatures (Knight, 2001; McDougall \& Oviatt, 2000; Oviatt \& McDougall, 2005a). As born globals (BGs) are found in a variety of locational contexts (e.g., Australia, Finland, Germany, USA) and are important contributors to their home-country GDP (e.g., Knight \& Kim, 2009; Kuivalainen, Sundqvist, \& Servais, 2007; Mort \& Weerawardena,

\footnotetext{
* Corresponding author. Tel.: +82 42629 7012; fax: +82 426298485 .

E-mail addresses: stephange@outlook.com (S. Gerschewski). Elizabeth.Rose@otago.ac.nz, Elizabeth.Rose@aalto.fi (E.L. Rose),

valerielindsay@uowdubai.ac.ae (V.J. Lindsay).

1 Tel.: +64 3479 8182; fax: +6434798173.

Tel.: +971 4367 1648; fax: +97143672754.

3 Several different terms are used to refer to firms that internationalise early and rapidly, including "international new ventures" (Oviatt \& McDougall, 1994), “instant exporters” (McAuley, 1999) and "born globals” (McKinsey \& Co., 1993). In this study, we adopt the term "born global", in line with the seminal work of Rennie (1993) and Knight and Cavusgil (1996).
}

2006), we examine the drivers of their early international performance and seek to understand how it differs from that of firms that follow a more traditional path to internationalisation. In this way, our study aims to contribute to the developing IE field.

The existing literature about BGs is broadly focussed on describing, understanding and interpreting the underlying rationales for their formation (Rialp, Rialp, \& Knight, 2005), while some work has also examined internationalisation patterns (e.g., Chetty \& Campbell-Hunt, 2004; Hashai \& Almor, 2004) and the role of networks (e.g., Loane \& Bell, 2006; Sharma \& Blomstermo, 2003). However, a comprehensive framework of the determinants of BG performance is still lacking; previous studies have tended to examine relatively specific aspects of international performance, such as marketing strategy (Gabrielsson, Gabrielsson, \& Seppälä, 2012; Knight, Madsen, \& Servais, 2004), rather than adopting a broader analysis that incorporates both internal and external influences. As Knight and Cavusgil (2004: 125) noted, "there has been almost no empirical research that examines the factors that drive the superior international performance of these young, highly entrepreneurial firms". While some recent work (e.g., Crick, 2009; Efrat \& Shoham, 2012; Jantunen, Nummela, Puumalainen, \& Saarenketo, 2008; Knight \& Kim, 2009) has begun to address this topic, we remain short of a deep understanding of BG performance. In addition, previous studies have tended to focus exclusively on BGs; Schwens and Kabst (2008) argued the need for comparisons of 
born globals and firms that adopt a more traditional path to internationalisation, an issue also raised by Fan and Phan (2007) and Zhang, Tansuhaj, and McCullough (2009).

In this study, we aim to address these gaps in the literature. Building on existing theory and using a mixed-methods approach that combines exploratory interviews and a web-based survey, we develop and test an integrated performance model that considers attributes of both the firm and the external environment. Thus, our study addresses the suggestion of Jones, Coviello, and Tang (2011: 643) that "given the variety of performance antecedents and outcomes relevant in IE, future research should acknowledge and try to examine a wide range of measures in an integrative manner" and follows the call of Coviello and Jones (2004) for combining positivist and interpretivist methods. Our integrated research design, which considers both exogenous and endogenous performance antecedents while undertaking a comparative assessment of BGs and non-BGs, offers a more holistic and fine-grained approach to understanding early performance of BGs. We position our study in the resource-based view and network perspective, building on the complementarity of these two theoretical approaches and their fit with our objective of taking an integrated look at BGs' international performance.

We test the model using a sample of 310 small- and mediumsized, internationally active firms from Australia and New Zealand. Our sample allows a comparison between BGs and traditionally internationalising firms, thus enhancing the interpretability and validity of the results and allowing the identification of BG-specific results.

The paper is structured as follows. The next section outlines the theoretical background of the study and reviews the literature, along with the development of the hypotheses. This is followed by the methodology and results sections. The paper concludes with the discussion and limitations of the study, and offers potential avenues for future research.

\section{Theoretical background and review of literature}

\subsection{Integration of theories}

Various theoretical frameworks have been used to examine BGs, including the resource-based view (RBV) of the firm (e.g., Knight \& Cavusgil, 2004), dynamic capabilities (e.g., Weerawardena, Mort, Liesch, \& Knight, 2007), the knowledge-based view (e.g., Gassmann \& Keupp, 2007), the network perspective on internationalisation (e.g., Chetty \& Campbell-Hunt, 2004), and organisational learning (e.g., Autio, Sapienza, \& Almeida, 2000). In this study, we employ the RBV and the network perspective as the key theoretical frameworks, building on their complementarity and following Freeman and Cavusgil (2007). While the RBV focuses on the firm's internal resources and capabilities, the network perspective emphasises the development of knowledge through external relationships. Combining them allows a more holistic examination of BGs' international performance, which is consistent with calls in the literature (e.g., McDougall \& Oviatt, 2000; Rialp et al., 2005). The results of our exploratory interviews supported the clear fit of the two theoretical perspectives to our study.

Widely employed in the field of strategic management, the RBV has also emerged as a dominant perspective in IE research (Young, Dimitratos, \& Dana, 2003), and is considered applicable for explaining the international activities of BGs (McDougall, Shane, \& Oviatt, 1994). The RBV places its primary emphasis on the firm and its internal resources and capabilities (Barney, 1991; Grant, 1991; Wernerfelt, 1984). Based on the assumptions that resources are distributed heterogeneously among firms within an industry and not fully mobile across firm borders, a key tenet of the RBV is that differences in resource endowments can lead to competitive advantage and superior firm performance. To create competitive advantage, a firm must possess resources that are valuable, rare, inimitable, and non-substitutable (Barney, 1991), with inimitability arguably the most important of these attributes (Newbert, 2007). In this study, we focus primarily on intangible resources, due to their high barriers to duplication by competitors and their relevance for achieving sustained competitive advantage and, therefore, superior performance (Hall, 1993).

Complementing the inward focus of the RBV, the outwardly focussed network perspective on internationalisation is a key theoretical basis in the IE literature (Coviello, 2006), and used widely in BG research (e.g., Freeman, Edwards, \& Schroder, 2006). The network perspective views the market as a collection of relationships among firms, such that organisations are interconnected and dependent on each other (Johanson \& Mattson, 1988). Coordination is achieved through interaction among firms within a broadly defined network, rather than primarily through a price mechanism or organisational hierarchy, and exchange relationships allow firms to access external resources and sell products. Thus, in the network approach, firms are viewed as being dependent on resources that are controlled by others, and access to these resources is gained as a function of the firm's position in the network. Relationships among firms evolve over time, and are characterised by mutual orientation and social exchange processes (Johanson \& Mattson, 1988; Johanson \& Vahlne, 1992).

Our joint consideration of the RBV and network approaches is consistent with Ciabuschi, Perna, and Snehota (2012), who adopted a resource interaction perspective to study the complexity of new venture formation. Arguing that the development of a new venture is a collective process that involves the re-assembling of resources from a variety of sources and under varying degrees of the firm's control, they emphasised the dynamic interactions and interdependencies of young businesses and their network relationships, and noted that the process of resource recombination influences both the network and the associated resources.

\subsection{International entrepreneurial orientation}

The entrepreneurship literature stresses the importance of individuals in considering a firm's internationalisation (Andersson, 2000). As BGs are generally viewed as being entrepreneurial in nature (Oviatt \& McDougall, 1994), we draw on the IE literature, especially its consideration of entrepreneurial orientation (Oviatt \& McDougall, 2005b).

The notion of entrepreneurial orientation pertains to a firm's strategic orientation and decision-making style, practices and methods, and can be viewed as a combination of proactiveness, innovativeness, and risk-taking (Covin \& Slevin, 1989), plus autonomy and competitive aggressiveness (Lumpkin \& Dess, 1996). Lee, Lee, and Pennings (2001) referred to entrepreneurial orientation as an important intangible organisational resource that offers sustained competitive advantage; firms cannot purchase entrepreneurial orientation from the market, so they must invest considerable time to cultivate it. International entrepreneurial orientation involves a proactive approach to identifying overseas markets, and is linked to managers' global vision and competitive posture (Covin \& Miller, 2014; Knight \& Cavusgil, 2004). Zhang et al. (2009) introduced the concept of international entrepreneurship capability, arguing that it enables firms to leverage resources and exploit opportunities in international markets, which is consistent with the RBV.

In the context of BGs, Knight and Cavusgil (2004) found that international entrepreneurial orientation tends to engender business strategies (e.g., quality focus) that are positively related to international performance. Similarly, Jantunen et al. (2008) 
reported that an entrepreneurial orientation is associated with better performance in international markets. Kuivalainen et al. (2007) found that international entrepreneurial orientation is a driver of the scale and scope of BG strategy, which, in turn, is related to stronger export performance. A positive association between international entrepreneurial orientation and international performance is consistent with the RBV, which posits that performance is related to the firm's resource endowments; in the context of BG firms, entrepreneurial qualities constitute important intangible human and organisational capital resources (Barney, 1991; Conner, 1991). Thus, based on the existing BG literature and the RBV, we hypothesise.

Hypothesis 1. International entrepreneurial orientation is positively related to the international performance of born global firms.

\subsection{Product/service quality}

The organisational capability to offer a high-quality product or service has been identified as a key intangible resource that is important to firm performance (Cho \& Pucik, 2005). Buzzell and Gale (1987) argued that customer-perceived quality is positively associated with profitability and noted the critical nature of product/service quality, with respect to performance. For BGs, Knight and Cavusgil (2004) found that high-quality product/ service was a driver of performance, and Knight et al. (2004) identified product quality, in combination with marketing competence and product differentiation, as being positively related to international performance. Rennie (1993) noted that BGs typically compete on the basis of quality and value created through innovative technology and product design, while Sharma and Blomstermo (2003) argued that product quality and reliability can be important factors that assist BGs in obtaining orders from foreign customers. Thus, viewing quality as a critical resource for BGs, we hypothesise.

Hypothesis 2. Product/service quality is positively related to the international performance of born global firms.

\subsection{Market and learning orientations}

Market orientation refers to the implementation of the marketing concept (Kohli \& Jaworski, 1990). Identifying it as key to marketing management and strategy, Narver and Slater (1990) operationalised market orientation as a combination of customer orientation, competitor orientation, interfunctional coordination, long-term focus, and profit objective. Hunt and Morgan (1995: 12) noted that market orientation is an intangible resource that "is socially complex in its structure, has components that are highly interconnected, has mass efficiencies, and is probably increasingly effective the longer it has been in place". In the domestic context, market orientation has been found to be positively related to organisational performance, new product success and overall performance (Baker \& Sinkula, 1999), profitability (Narver \& Slater, 1990) and organisational commitment (Jaworski \& Kohli, 1993).

Market orientation has also been examined for BGs. Knight and Cavusgil (2004) found that US born globals' business strategies tend to be functions of their international marketing orientations and, in turn, business strategies are drivers of international performance. Ruokonen and Saarenketo (2009) noted that strong market orientation, combined with learning orientation, may provide a strong indication of whether companies are able to achieve sustained competitive advantage. Based on these findings, and consistent with the RBV, our third hypothesis is.

Hypothesis 3. Market orientation is positively related to the international performance of born global firms.
Learning orientation has its foundation in organisational learning theory, which views the firm as a learning entity. Organisational learning, defined as the "process of improving actions through better knowledge and understanding" (Fiol \& Lyles, 1985: 803), tends to be positively associated with business performance (Senge, 1990). Slater and Narver (1995) suggested that learning orientation complements market orientation, and provides a foundation for competitive advantage. A highly intangible organisational resource (e.g., Hult, Ketchen, \& Nichols, 2003), learning orientation has been found to be positively related to organisational performance, in terms of new product success, improvement in relative market share, and overall performance (Baker \& Sinkula, 1999), and innovativeness (Hult, Hurley, \& Knight, 2004). Zahra, Ireland, and Hitt (2000) found support for a positive relationship between international expansion and the breadth, depth and speed of technological learning. Baker and Sinkula (1999) concluded that the combination of strong market and learning orientations is associated with long-term competitive advantage.

In the context of BGs, Jantunen et al. (2008) and Kropp, Lindsay, and Shoham (2006) found learning orientation to be positively related to international performance. The concept of "learning advantage of newness" (Autio et al., 2000) suggests that firms that internationalise early after inception are more flexible, in terms of being able to quickly learn the competencies required for growth in foreign markets. Thus, we hypothesise.

Hypothesis 4. Learning orientation is positively related to the international performance of born global firms.

\subsection{Networks}

Hypotheses 1-4 pertain to firm-specific resources. However, the network perspective on internationalisation argues that a firm cannot be analysed in isolation, but must be studied in the wider context of the market environment in which it operates (Johanson \& Mattson, 1988). Networks are considered to be especially critical for BGs. Coviello and Munro (1997) found that BGs' foreign market choice and entry mode decisions are shaped by formal and informal network relationships, often resulting from a connection with a large international partner. This supports Johanson and Vahlne (1992), who argued that the development of business relationships is critical in the market entry process, while Chetty and Stangl (2010) found that firms with more diverse network relationships were more likely to undertake radical internationalisation and innovation.

The concept of social capital recognises the intangible implications that arise from inter-firm relationships within a network (Nahapiet \& Ghoshal, 1998). In the context of internationalisation, Chetty and Agndal (2007) argued that social capital can trigger and enable entry mode change (e.g., from lowto high-commitment), and Zhou, Wu, and Luo (2007) highlighted the importance of social capital for BGs, noting the attendant information benefits, such as advice about foreign market opportunities and the potential for experiential learning. Similarly, Blomstermo, Eriksson, Lindstrand, and Sharma (2004) found that firms gain knowledge about local and international networks primarily through their international experiences.

The role of BG managers' personal networks is a recurring theme in the IE literature. For example, Freeman et al. (2006) emphasised the role of managers' extensive personal network contacts in BGs' development and rapid internationalisation. McDougall et al. (1994) found that the personal contacts of BG managers facilitated international expansion, and argued that opportunistic behaviour, which has negative implications for hybrid organisational structures, could be lessened when BGs' 
partners develop from the founders' personal networks. Other benefits of BG managers' personal networks have been identified, such as the development of inter-organisational networks (Chetty \& Agndal, 2008), driving early internationalisation (Zucchella, Palamara, \& Denicolai, 2007), serving as a main source of network knowledge (Zou \& Ghauri, 2010), and contributing to firms' international market venturing (Eberhard \& Craig, 2013). Andersson and Wictor (2003) argued that personal contacts are key to international strategy implementation, due to BGs' young age and lack of stability in routines, systems and processes. With respect to personal networks, Johanson and Vahlne (2009) noted that the "liability of outsidership" is more important than the liability of foreignness, making network insidership crucial for firm success. Given the literature's emphasis on the importance of personal networks for the internationalisation of BGs, we hypothesise.

Hypothesis 5. The leveraging of management's personal networks is positively related to the international performance of born global firms.

\subsection{Business strategy}

Porter (1980)'s typology of three generic strategies includes cost leadership, differentiation, and focus. In a cost leadership strategy, the firm's goal is to become the lowest-cost producer in an industry, which can be achieved through factors such as economies of scale and proprietary technology. A firm pursuing a differentiation strategy competes on the basis of its uniqueness with respect to dimensions that are valued by the buyer, such as product features and image. In a focus approach, a firm tailors its strategy to a particular industry segment, adopting either a cost or a differentiation focus within its narrow market.

Findings from the export literature indicate a positive relationship between the use of a differentiation strategy and export performance (Baldauf, Cravens, \& Wagner, 2000). Many BGs adopt a niche strategy, which is effectively Porter's focus strategy with differentiation, in their internationalisation efforts (e.g., Liesch, Steen, Middleton, \& Weerawardena, 2007; Rennie, 1993), and this has been positively associated with international performance (Knight \& Cavusgil, 2005). Miller (1986) suggested that the use of a niche differentiation strategy may be appropriate for small firms with simple structures; most BGs fit this categorisation. Accordingly, we hypothesise.

Hypothesis 6. The extent of pursuit of a niche strategy is positively related to the international performance of born global firms.

\subsection{External environment}

The BG literature has tended to focus more on formation processes and entrepreneurial and organisational characteristics than on the firm's external environment and its relationship with performance (Aspelund, Madsen, \& Moen, 2007). The external environment has been considered primarily in terms of factors that facilitate the development of BGs, such as advances in communications, increasingly reliable and economical transportation, and improved technology (Madsen \& Servais, 1997). However, market attractiveness - both domestic and export - has also been investigated. Chetty and Campbell-Hunt (2004) noted that small and geographically isolated domestic markets facilitate the emergence of BGs, and Moen (2002) found that home market unattractiveness and export market attractiveness are significantly higher for BGs than for other exporters. More broadly, in the context of exporting, there is evidence that market attractiveness and performance are positively related, either directly (Madsen, 1989) or indirectly (Mavrogiannis, Bourlakis, Dawson, \& Ness, 2008).
The network view posits that successful internationalisation may depend more on the firm's position in a foreign network than on its firm-specific advantages (Johanson \& Mattson, 1988). In this respect, the market's degree of internationalisation, defined as the "extent, intensity, and degree of relationships across borders in the industry in general" (Madsen \& Servais, 1997: 572), is important. Johanson and Mattson (1988) argued that firms operating in highly internationalised markets may internationalise faster and establish sales subsidiaries earlier, due to a stronger need for integration and co-ordination. A highly internationalised market may also provide firms with the benefits associated with a wider international network. Therefore, we expect that BGs will experience stronger performance in markets that are more attractive and more internationalised.

Hypothesis 7. The attractiveness of main foreign markets is positively related to the international performance of born global firms.

Hypothesis 8. The degree of internationalisation of the market is positively related to the international performance of born global firms.

Fig. 1 summarises the eight hypotheses in an integrated conceptual model.

\section{Methodology}

There is no universally accepted definition of a born global firm; see Kuivalainen, Saarenketo, and Puumalainen (2012) for a discussion of the complexity of this issue in the context of Finnish knowledge-intensive SMEs. While Coviello, McDougall, and Oviatt (2011) note that the terms "international new venture" and "born global" have been used interchangeably in the literature, Madsen (2013) recommends using the speed, scope and extent of the firm's international activities in defining BGs. For this study, we operationalise BGs using three criteria. First, the firm must have started to internationalise within three years of its establishment; this is consistent with many BG studies, including Knight and Cavusgil (2004) and Mort and Weerawardena (2006). Second, the firm must have at least $25 \%$ of its total sales from international markets within the first three years (e.g., Andersson \& Wictor, 2003; Knight \& Cavusgil, 2004). Third, firms must be independently owned (i.e., start-up operations or spin-offs from other firms, and excluding current subsidiaries), following Zahra (2005). ${ }^{4}$

We study the determinants of performance in BGs using a sequential mixed-methods approach, with exploratory interviews followed by a web-based survey (e.g., Teddlie \& Tashakkori, 2003). The semi-structured interviews with top managers of BGs from a variety of industries offer depth of understanding, while the questionnairebased data offer breadth. The use of mixed methods in international business and international entrepreneurship research is increasingly viewed as highly appropriate (e.g., Crick \& Chaudry, 2010; Hurmerinta-Peltomäki \& Nummela, 2006). This approach is particularly relevant for this study, as using methodological variety allows for the complexity of the phenomenon to be explored more fully. Research on born globals remains theoretically under-developed, reflective of both the multi-faceted nature of international business more generally and the relative newness of research attention to these rapidly internationalising firms; thus, the use of the broader mixed-method approach allows for wider exploration (Hurmerinta-Peltomäki \& Nummela, 2006). Further, the use of both fully exploratory and theory testing approaches allows a greater contribution to an existing base of

\footnotetext{
${ }^{4}$ Of course, firms can be classified in many different ways. For example, some of the firms that we treat as non-BGs might be considered as born-again globals under the classification of Bell, McNaughton, and Young (2001). In this paper, our primary focus is on studying the performance of BG firms, and identifying systematic differences between BGs and those firms that are not BGs.
} 


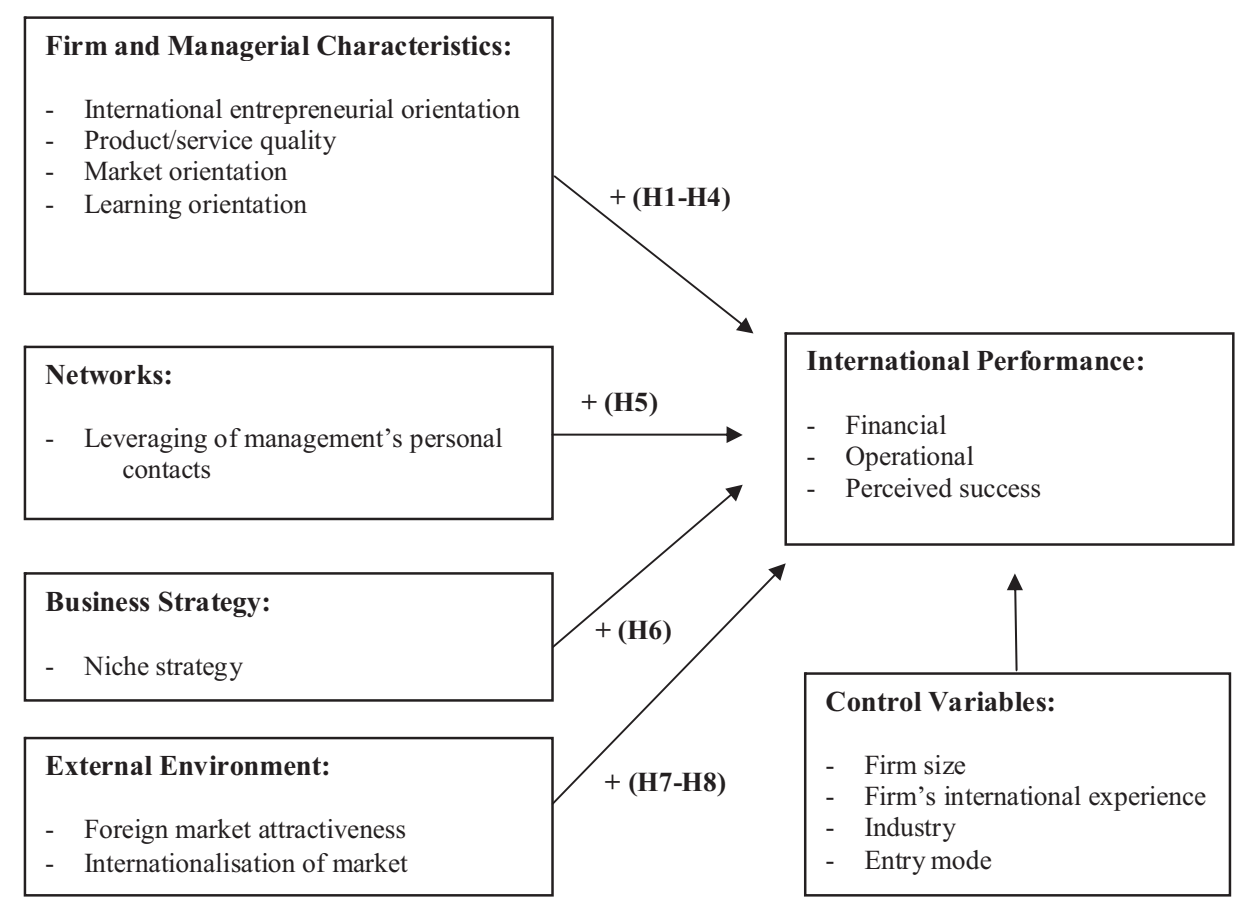

Fig. 1. Conceptual model of the study.

knowledge (Teddlie \& Tashakkori, 2003) regarding these stillunderexplored born global firms (Loane \& Bell, 2006).

The sequential use of interviews and questionnaires contributes to construct validity (Edmondson \& McManus, 2007), offers a more holistic and contextual understanding (Jick, 1979), and provides a "deeper, broader, and more descriptive illustration of the phenomenon" (Hurmerinta-Peltomäki \& Nummela, 2006: 452). The qualitative/quantitative sequencing allows the qualitative results to provide input into the development of the survey instrument (Teddlie \& Tashakkori, 2003); this allowed the incorporation into the questionnaire of issues raised in the interviews that were clearly important to managers but that had not previously been explicitly addressed in the literature.

Most BG studies have been based on a single methodology, either purely quantitative (e.g., Jantunen et al., 2008) or purely qualitative (e.g., Liesch et al., 2007; Mort \& Weerawardena, 2006). In the wider international business (IB) literature, mixed-method studies also tend to be in the minority (Hurmerinta-Peltomäki \& Nummela, 2006). Still, scholars have emphasised the suitability of mixed methods for business research, and have called for wider adoption of this more holistic approach (e.g., Bazeley, 2008; Rialp et al., 2005).

Our focus on firm behaviour lends itself particularly well to the combined use of qualitative and quantitative approaches. We utilise the mixed methodology for what Greene, Caracelli, and Graham (1989) describe as "development" and "initiation". Development pertains to using the results from one method to inform the other, in order to enhance validity, while initiation involves the combination of results from different methods to develop broader and deeper interpretations. In this study, the development aspect consists of using exploratory interviews to help to inform and refine the measurement of constructs in the quantitative survey instrument. The initiation purpose is served by using the results from the qualitative interviews and quantitative survey jointly, to develop a richer and more in-depth understanding of early performance among BGs.

Of course, the use of mixed methods is not a panacea; see Jick (1979). The approach is subject to challenges, including the need to identify an appropriate balance between qualitative and quantitative results, especially when they offer conflicting messages. Replication of a mixed-methods study can be extremely difficult, which may limit the perceived generalisability of the results. Despite these challenges, we believe that the objectives of this study are well-served by the use of a sequential qualitative/ quantitative design. The adoption of mixed methods increases the study's robustness and rigour, thus enhancing its validity and permitting a deeper examination of the determinants of international performance for BGs.

\subsection{Qualitative component: interviews}

Semi-structured, in-depth interviews were carried out with eight BGs in New Zealand (5) and Australia (3), with three goals: seeking initial validation of the conceptual model, informing the development of the survey instrument, and obtaining rich insights into early international performance among BGs. Company details were obtained through on-line sources (e.g., government export agency websites) and verified using the Dun \& Bradstreet company database. The sampling process followed a purposive approach (Miles \& Huberman, 1994) with the main criteria being that the firms were BGs, had international operations (e.g., exporting, licensing), and represented a variety of industries; the interviewed firms represented the ICT, manufacturing, food, and education industries, in line with the integrated approach of the study. The approximately hour-long interviews were conducted either faceto-face on the companies' premises (3) or at a distance (5) via telephone or Skype. Table 1 summarises the eight firms' key characteristics. The interviews were audio-recorded and transcribed prior to qualitative data analysis, using the NVivo 8 software, through which emerging patterns and themes were identified, consistent with the guidelines of Miles and Huberman (1994). The use of computer-assisted qualitative data analysis (CAQDAS), including NVivo, offers benefits, such as enhanced interpretation of qualitative data as well as increased rigour, trustworthiness and validity, which are difficult to obtain with manual analytic approaches (e.g., Lindsay, 2004; Sinkovics \& Penz, 2011; Sinkovics, Penz, \& Ghauri, 2008). NVivo is an established and 
Table 1

Profile of interviewed companies. ${ }^{a}$

\begin{tabular}{|c|c|c|c|c|c|c|c|c|}
\hline & FOOD & ICT1 & ICT2 & EDUC & OIL & WINE & MFG1 & MFG2 \\
\hline Number of employees & 15 & 70 & 75 & 32 & 50 & 8 & 15 & 42 \\
\hline Industry & Food & ICT & ICT & Education & Oil and Gas & Wine & Manufacturing & Manufacturing \\
\hline Year of establishment & 2001 & 2001 & 1999 & 2003 & 2002 & 1998 & 2003 & 1994 \\
\hline $\begin{array}{l}\text { Year of first } \\
\text { internationalisation }\end{array}$ & 2003 & 2002 & 2001 & 2005 & 2003 & 1998 & 2006 & 1997 \\
\hline $\begin{array}{l}\text { International sales } \\
\text { ratio three years after } \\
\text { firm establishment }\end{array}$ & $60 \%$ & $99 \%$ & $98 \%$ & $51 \%$ & $50 \%$ & $75 \%$ & $40 \%$ & $30 \%$ \\
\hline First international markets & $\begin{array}{l}\text { USA, } \\
\text { Australia, } \\
\text { Singapore }\end{array}$ & $\begin{array}{l}\text { South } \\
\text { Korea, USA, } \\
\text { UK, Japan, } \\
\text { Taiwan }\end{array}$ & $\begin{array}{l}\text { France, } \\
\text { Other } \\
\text { Europe }\end{array}$ & $\begin{array}{l}\text { Singapore, } \\
\text { Canada }\end{array}$ & Middle East & $\begin{array}{l}\text { USA, UK, } \\
\text { Europe }\end{array}$ & $\begin{array}{l}\text { Hong Kong, } \\
\text { Singapore, UK, } \\
\text { USA, Taiwan }\end{array}$ & USA, UK, Australia \\
\hline $\begin{array}{l}\text { Entry mode to first } \\
\text { international markets }\end{array}$ & Export & $\begin{array}{l}\text { Export, } \\
\text { WOS(M) }\end{array}$ & Export & $\begin{array}{l}\text { Export, } \\
\text { Strategic } \\
\text { alliance }\end{array}$ & $\begin{array}{l}\text { Export, } \\
\text { Joint } \\
\text { venture }\end{array}$ & Export & Export, WOS(S) & $\begin{array}{l}\text { Licensing, Export, } \\
\text { Strategic alliance }\end{array}$ \\
\hline Sales focus & $\mathrm{B} 2 \mathrm{C}$ & B2B & $\mathrm{B} 2 \mathrm{~B}$ & B2B & B2B & $\mathrm{B} 2 \mathrm{C}$ & $\mathrm{B} 2 \mathrm{C}$ & $\mathrm{B} 2 \mathrm{~B}$ \\
\hline
\end{tabular}

a In order to preserve anonymity, the company names are not revealed.

b $\operatorname{WOS}(\mathrm{M})=$ wholly owned manufacturing subsidiary, $\mathrm{WOS}(\mathrm{S})=$ wholly owned sales subsidiary.

widely used software programme that is commonly adopted for qualitative research (Bazeley, 2007). The sample of eight interviewed companies, which is consistent with recommended sample sizes (e.g., Kuzel, 1992; Guest, Bunce, \& Johnson, 2004), provided considerable saturation of responses as the interviews progressed (Glaser \& Strauss, 1967).

The interviews provided support for many aspects of the conceptual model. In particular, the notion of international entrepreneurial orientation was a recurring theme. As the interviewees discussed this notion in terms of managers' global vision and perseverance with doing international business, these findings were used in the operationalisation of the international entrepreneurial orientation construct in the questionnaire. Other key themes from the interviews were a strong focus on product/ service quality and the role of personal networks, which are both consistent with the conceptual model. The interviewed companies adopted a variety of different performance measures, with particular importance given to financially based measures, such as return on investment (ROI) and international sales growth; these qualitative results helped to inform the survey instrument, with respect to operationalising the performance construct.

\subsection{Quantitative component: survey sample}

The sampling frame for the web-based survey consisted of exporting firms that were based in Australia and New Zealand and established between 1999 and 2009. As our focus is on BGs' early international performance - within the first five years after initial internationalisation - we chose relatively young firms, in order to minimise the potential for memory bias among respondents. Because BG firms exist across industries, from high-technology (e.g., Crick \& Jones, 2000) to arts and crafts (e.g., McAuley, 1999), the sampling frame reflected this wide range of industries.

The sampling frame was developed using the Dun \& Bradstreet database. In total, 2000 firms were invited to participate in the survey: 1000 each from New Zealand and Australia. Initially, a postal letter containing the link to access the web-based survey was sent to all 2000 companies; this was followed by two sets of reminder e-mails. The final sample consists of 310 usable responses, corresponding to a net response rate of $15.5 \%$.

Because we rely on data for the dependent and explanatory variables from single respondents, we checked for common method bias (Podsakoff \& Organ, 1986). Harman's single-factor test revealed multiple factors, with the largest accounting for $26 \%$ of the variance, suggesting that common method bias is not a serious concern in our data (Podsakoff, MacKenzie, Lee, \& Podsakoff, 2003). The mixed methods design, using both interviews and a survey, conducted at different times, also reduces the potential for common method bias in this study, as do the facts that the respondent firms are quite small (68.4\% with fewer than 20 full-time-equivalent employees) and that the respondents are overwhelmingly (79.0\%) owners and/or CEOs.

\subsection{Measurement}

We employ previously validated measures from the literature, which are supplemented by the interview findings. Variables for the models are developed using exploratory factor analysis and refined using reliability analysis. Most of the variables are multiitem factors, based on seven-point Likert scale survey items, where 1 represents strong disagreement/not important at all, and 7 represents strong agreement/extremely important. The Cronbach's $\alpha$ values for the scales employed in the analysis range from .72 to .94 , indicating acceptable internal consistency (Nunnally, 1978); see Table 2 for details regarding the variables and the scale reliabilities.

\subsection{Dependent variables}

We are interested in modelling international performance during the first five years of cross-border activity. Performance can be measured using subjective and objective indicators (Hult et al., 2008). There are challenges associated with the use of objective performance measures in the context of small firms, such as reluctance by owners/entrepreneurs to reveal actual performance data to researchers (Sapienza, Smith, \& Gannon, 1988). Thus, like many BG studies (e.g., Jantunen et al., 2008), we employ subjective performance measures, which tend to be positively correlated with objective measures (Dess \& Robinson, 1984).

The export and BG literatures display wide heterogeneity in terms of performance measures (Katsikeas, Leonidou, \& Morgan, 2000; Sousa, Martinez-Lopez, \& Coelho, 2008). Venkatraman and Ramanujam (1986) distinguished among three types of performance: financial and operational performance, and organisational effectiveness. This conceptualisation was also adopted by Hult et al. (2008), who used financial and operational performance and overall effectiveness. Shoham (1998) identified three dimensions: sales, profitability, and change (in sales and profitability). In the EXPERF scale, Zou, Taylor, and Osland (1998) developed the three dimensions of financial, and strategic export performance, and 
Table 2

Summary of created factors and Cronbach's $\alpha$.

\begin{tabular}{|c|c|c|c|}
\hline Construct & $\begin{array}{l}\text { Variance } \\
\text { explained (\%) }\end{array}$ & $\begin{array}{l}\text { Cumulative } \\
\text { variance } \\
\text { explained (\%) }\end{array}$ & Cronbach's $\alpha$ \\
\hline $\begin{array}{l}\text { International entrepreneurial orientation: Global vision } \mathcal{E} \text { perseverance ( } 6 \text { items) } \\
\text { World instead of New Zealand/Australia as firm's marketplace } \\
\text { Persistence in doing international business } \\
\text { Vision to be a truly global company } \\
\text { Long-term, strategic approach to internationalisation } \\
\text { Strong determination to do international business } \\
\text { Regular communication to employees about mission to be successful overseas }\end{array}$ & 50.5 & & .91 \\
\hline $\begin{array}{l}\text { International entrepreneurial orientation: innovativeness E proactiveness ( } 6 \text { items) } \\
\text { Seek out new ways to do things } \\
\text { Initiate actions to which other companies respond } \\
\text { Introduction of improvements and innovations in company } \\
\text { Excel at identifying opportunities } \\
\text { Try to take initiative in every situation } \\
\text { Company is creative in the way it operates }\end{array}$ & 14.7 & 65.2 & .86 \\
\hline $\begin{array}{l}\text { Product/service quality (3 items) } \\
\text { Praise for product/service quality by international customers } \\
\text { Better product/service quality than major competitors } \\
\text { International customers' conviction of company's high product/service quality offering }\end{array}$ & 77.7 & 77.7 & .85 \\
\hline $\begin{array}{l}\text { Market orientation: customer orientation ( } 7 \text { items) } \\
\text { Objectives driven by customer satisfaction } \\
\text { Monitoring level of commitment to serving customer needs } \\
\text { Strategy based on understanding of customer needs } \\
\text { Functions are integrated in serving the needs of target market } \\
\text { Business strategies are driven by beliefs about how to create better value for customers } \\
\text { Close attention to after-sales service } \\
\text { Systematic and frequent measurement of customer satisfaction }\end{array}$ & 43.7 & & .83 \\
\hline $\begin{array}{l}\text { Market orientation: competitor orientation (4 items) } \\
\text { Sharing of information about competitors' strategies } \\
\text { Free communication about customer experiences within company } \\
\text { Discussion of competitors' strengths and strategies } \\
\text { Target opportunities for competitive advantage }\end{array}$ & 8.9 & 52.6 & .72 \\
\hline $\begin{array}{l}\text { Learning orientation (11 items) } \\
\text { Company's ability to learn as key to competitive advantage } \\
\text { Common purpose throughout company } \\
\text { Reflect on shared assumptions about way of doing business } \\
\text { Learning as key to improvement } \\
\text { Agreement on company vision across all levels, functions, and divisions } \\
\text { High value of "open-mindedness" } \\
\text { Employee learning as investment not expense } \\
\text { Commitment of all employees to the company } \\
\text { Encouraging employees to "think outside the box" } \\
\text { Learning as key commodity to guarantee survival of the company }\end{array}$ & 52.9 & 52.9 & .91 \\
\hline $\begin{array}{l}\text { Leveraging of management's personal networks ( } 2 \text { items) }{ }^{\mathrm{a}} \\
\text { Importance of personal contacts as provider of networks for internationalisation }\end{array}$ & 70.5 & 70.5 & .56 \\
\hline $\begin{array}{l}\text { Niche strategy ( } 8 \text { items) } \\
\text { Targeting of specialised needs in international markets } \\
\text { Product/service as new and innovative way of meeting a demand } \\
\text { Emphasis on uniqueness of product/service in international marketing } \\
\text { Product/service highly specialised for international markets } \\
\text { Product/service unique with respect to technology } \\
\text { International strategy to serve an unmet market need } \\
\text { Focus on exploiting niche in market } \\
\text { Targeting of relatively new and 'untapped' markets worldwide }\end{array}$ & 58.9 & 58.9 & .90 \\
\hline $\begin{array}{l}\text { Foreign market attractiveness ( } 2 \text { items) } \\
\text { Foreign market size } \\
\text { Foreign market potential }\end{array}$ & 66.2 & 66.2 & .80 \\
\hline $\begin{array}{l}\text { Internationalisation of the market ( } 4 \text { items) } \\
\text { Degree of internationalisation of the industry } \\
\text { Degree of interdependence of business relationships within the industry, worldwide } \\
\text { Number of international customers, distributors, competitors, suppliers and other } \\
\text { business partners in the industry } \\
\text { Importance of maintaining business relationships due to the interconnectedness and } \\
\text { integration of the industry }\end{array}$ & 60.4 & 60.4 & .78 \\
\hline $\begin{array}{l}\text { International performance: financial (5 items) } \\
\text { International sales volume } \\
\text { International sales growth } \\
\text { International profitability } \\
\text { Overall international performance } \\
\text { Return on investment (ROI) from international business }\end{array}$ & 62.0 & & .94 \\
\hline $\begin{array}{l}\text { International performance: operational ( } 7 \text { items) } \\
\text { Market share in international markets } \\
\text { New product/service introduction in international markets } \\
\text { Time to market for new products/services internationally } \\
\text { Number of successful new products/services in international markets }\end{array}$ & 10.2 & 72.2 & .91 \\
\hline
\end{tabular}


Table 2 (Continued)

\begin{tabular}{|c|c|c|c|}
\hline Construct & $\begin{array}{l}\text { Variance } \\
\text { explained (\%) }\end{array}$ & $\begin{array}{l}\text { Cumulative } \\
\text { variance } \\
\text { explained (\%) }\end{array}$ & Cronbach's $\alpha$ \\
\hline $\begin{array}{l}\text { Global reach (i.e., presence in strategically located countries worldwid } \\
\text { International reputation of the firm } \\
\text { Gaining a foothold in international markets }\end{array}$ & & & \\
\hline $\begin{array}{l}\text { International performance: perceived success ( } 2 \text { items) } \\
\text { Success of main international business } \\
\text { Success of main international business from competitors' perspective }\end{array}$ & 83.4 & 83.4 & .80 \\
\hline
\end{tabular}

a The two items are not combined due to the low Cronbach's $\alpha$ and are used as two separate explanatory variables in regression models.

satisfaction with export venture. Based on Cavusgil and Zou (1994), Styles (1998) used sales growth and profitability, achievement of strategic objectives, and perception of success as performance measures. Sousa (2004) categorised export performance measures into sales-, profit-, and market-related, general and miscellaneous indicators, while Katsikeas et al. (2000) differentiated among economic (sales-, profit-, and market share-related), non-economic (product-, and market-related, and miscellaneous), and generic measures. The literature generally emphasises the importance of incorporating non-financial measures along the traditional financial indicators when investigating performance (e.g., Chenhall \& Langfield-Smith, 2007; Verbeeten \& Boons, 2009).

In our study, we examine multiple dimensions of international performance, following Venkatraman and Ramanujam (1986), Chenhall and Langfield-Smith (2007), and Hult et al. (2008): Financial, Operational, and Perceived success. In this process, we incorporate measures on each of the three performance dimensions introduced by Walker and Ruekert (1987): effectiveness, efficiency, and adaptability. The performance measures are weighted by multiplying the levels of importance and satisfaction for each measure, as indicated by the respondents; this weighting approach is aimed at offering a more fine-grained view of performance, and has been adopted in previous studies (e.g., Gupta \& Govindarajan, 1984). Respondents were asked to evaluate international performance for the first five years following their company's initial internationalisation, in line with Thirkell and Dau (1998).

\subsection{Explanatory and control variables}

We test our eight hypotheses using 12 explanatory variables, which are developed based on the existing literature and interviews. The notion of international entrepreneurial orientation (H1) is represented using two variables: Global vision $\mathcal{E}$ perseverance and Innovativeness $\mathcal{E}$ proactiveness. The items used to develop these factors are drawn from Knight and Cavusgil (2004), Hughes and Morgan (2007) and the interview findings, and follow Frishammar and Andersson's (2009) call for developing more suitable operationalisations of entrepreneurial orientation for SMEs. The measure of Product/service quality (H2) is adopted from Menon, Jaworski, and Kohli (1997).

Market orientation (H3) is operationalised using two factors, drawing on Narver and Slater's (1990) conceptualisation, which is grounded in organisational culture: Customer orientation and Competitor orientation. Learning orientation (H4) is based on items adapted from the established measure of Sinkula, Baker, and Noordewier (1997).

Two explanatory variables pertain to senior management's personal networks for facilitating internationalisation (H5), which Andersson and Wictor (2003) emphasised as particularly important for BGs: Importance of personal contacts and Amount of preexisting personal networks. The IE literature includes several quantitative studies that deal with networks (e.g., Al-Laham \& Souitaris, 2008; Loane \& Bell, 2006; Zhou et al., 2007). However, the existing Likert-type scales, such as those pertaining to guanxi networks (Zhou et al., 2007) and network experiential knowledge (Blomstermo et al., 2004), do not quite capture what we seek to measure in our study. Therefore, we developed our measures based on Andersson and Wictor (2003), due to their applicability to the nature of our study and their close alignment with our qualitative findings. More specifically, Andersson and Wictor (2003) found that managers of Swedish BGs actively used personal networks as tools for implementing successful global strategies. Based on Andersson and Wictor's (2003) findings, we operationalised networks as the extent and importance of personal networks, with respect to the internationalisation of BGs. Our operationalisation of networks is consistent with qualitative IE research, such as Freeman et al. (2006) and Zou and Ghauri (2010), which emphasises the importance of personal networks for the internationalisation process among BGs.

With respect to the firm's strategy (H6), the Niche strategy factor is developed using items from Liesch et al. (2007), Moen (2002), and the interviews, and include the extent of product/service specialisation for international markets and the targeting of new and relatively untapped markets. The final two explanatory variables pertain to the firm's external environment. Foreign market attractiveness (H7) draws on Cavusgil and Zou (1994) and Madsen (1989), and includes the size and potential of international markets. The Internationalisation of the market (H8) measure is based on Madsen and Servais (1997), addressing the interdependence and extent of international relationships, and the extent of international customers, distributors, competitors, suppliers, and other business partners, within the industry.

In addition to the explanatory variables, we control for the firm's international experience, measured as the number of years it has been involved in international activities (e.g., Francis \& CollinsDodd, 2000), and its size, operationalised as annual gross sales (e.g., Jantunen et al., 2008), along with a dummy variable to distinguish between manufacturing and other sectors (e.g., Brouthers, 2002). ${ }^{5}$ While most BG studies have focused solely on exporters (e.g., Knight \& Kim, 2009), our sample extends to firms that have used other modes of internationalisation (e.g., licensing, strategic alliance). Due to the potential implications of entry mode choice on performance (e.g., Brouthers \& Nakos, 2004; Jones \& Young, 2009; Ripolles \& Blesa, 2012), we include a dummy variable pertaining to the firm's mode of entering its first foreign market, where 1 represents exporting.

\section{Analysis and results}

\subsection{Sample}

Our sample of 310 firms consists of 147 BGs (102 New Zealand and 45 Australian) and 163 non-BGs (101 New Zealand and 62 Australian). The BGs and non-BGs in the sample are quite comparable on most key measures, apart from their international

\footnotetext{
5 This is admittedly a coarse distinction, but model experimentation with finergrained distinctions did not provide additional insights.
} 
Table 3

Key comparisons between BGs and non-BGs.

\begin{tabular}{lll}
\hline & Born globals & Non-born globals \\
\hline $\begin{array}{l}\text { Number of firms } \\
\text { Number of employees }\end{array}$ & 147 & 163 \\
$\begin{array}{l}\text { International sales } \\
\text { three years after } \\
\quad \text { company establishment }\end{array}$ & 23.4 & 28.5 \\
Company age (in years) & $71.6 \%$ & $5.9 \%$ \\
Industry sectors & 9.6 & \\
& Manufacturing & Manufacturing \\
& $(27.2 \%)$ & $(31.3 \%)$ \\
& Service (38.8\%) & Service (37.4\%) \\
Company's annual gross & Other (34.0\%) & Other (31.3\%) \\
sales in 2009 (NZ/A\$) & $1-5$ million & $1-5$ million \\
\hline
\end{tabular}

sales three years after establishment; see Table 3 for an overview of the key sample characteristics. ${ }^{6}$

\subsection{Modelling and hypothesis testing}

We test the hypotheses using ordinary least squares regression modelling. Residual analysis revealed no evidence of heteroscedasticity, outliers or influential observations in any of the models. Despite some correlations that differ significantly to zero, as shown in Tables 4 (BG) and 5 (non-BG), variance inflation factors (VIF) all below 3.0 indicate no problem with multicollinearity. Our models account for between $40 \%$ and $57 \%$ of the variation in international performance for the BG firms in our sample, and $31-44 \%$ for the non-BG sample; these goodness-of-fit levels compare quite well to other studies in the performance literature. Table 6 shows the results of modelling the three measures of international performance for both the BG and non-BG samples.

We use the born global sample to test the hypotheses. The varying results across the first three columns of Table 6 reinforce the importance of considering the different of performance. Hypothesis 1, regarding international entrepreneurial orientation, is supported for the Financial performance and Operational performance measures, with positive coefficients (at least $p<.10$ ) for both Global vision $\mathcal{E}$ perseverance and Innovativeness $\mathcal{E}$ proactiveness. Hypothesis 2 receives strong support $(p<.01)$ for all three performance measures, reflecting the importance of high product/service quality for small firms. Hypothesis 3, pertaining to market orientation, receives partial support; although Customer orientation displays no marginal relationship with performance, Competitor orientation is positively related to Financial performance $(p<.10)$ and Perceived success $(p<.05)$. None of the other hypotheses is supported for the BG sample, and Hypothesis 6 (niche strategy) is strongly contradicted $(p<.01)$ with respect to Financial performance.

Among the control variables, Company's annual gross sales is positively related to all three performance dimensions, while the estimated coefficients for the export entry mode dummy variable suggest that entering the first overseas market by exporting is marginally associated with higher financial and operational performance.

We also estimate the models for the non-BG sample, to enable a comparison with the BG results and to improve their interpretability relative to those for more traditionally internationalising

\footnotetext{
${ }^{6}$ BGs have often been observed in knowledge-intensive industries (e.g., Coviello \& Munro, 1997; Crick \& Jones, 2000; Gassmann \& Keupp, 2007). The bulk of the service-sector firms in our sample operate in knowledge-intensive environments, and the proportions are nearly identical for the BG and non-BG subsamples $(38.8 \%$ and $37.4 \%$, respectively). However, the inclusion of a service-sector dummy variable did not improve our estimated models.
}

firms. With regard to international entrepreneurial orientation, we observe positive relationships between Global vision \& perseverance and two of the performance dimensions: Operational performance $(p<.01)$ and, distinct to the BG results, Perceived success $(p<.05)$. In contrast to the BG sample, Innovativeness $\mathcal{E}$ proactiveness contributes no marginal explanatory power for any of the three international performance measures. Consistent with the BG results, we find positive relationships between Product/service quality and both Financial performance $(p<.05)$ and Perceived success $(p<.01)$; however, we find no significant marginal association between quality and Operational performance. In contrast to the BG sample, Competitor orientation is not significantly related to performance, but the pursuit of a Niche strategy is associated with stronger Operational performance $(p<.01)$ and Foreign market attractiveness is positively related to Financial performance $(p<.05)$. While neither of the network variables contributes marginal explanatory power in the BG models, stronger Pre-existing personal networks are positively related $(p<.05)$ to Financial performance among the traditionally internationalising sample. For the non-BGs, the results for the control variables are rather complementary to those observed for the BG sample, with less international experience and operation in the manufacturing sector associated with stronger Financial and Operational performance.

\section{Discussion}

This study has developed and tested a performance model for BGs, by adopting a comparative approach with traditionally internationalising firms and drawing on the RBV and the network perspective on internationalisation. Our study contributes to the literature in several ways. Firstly, by modelling the combined effects of a variety of performance drivers, we offer an integrated perspective on BG performance. We believe that, consistent with the call by Jones et al. (2011), our model's more holistic approach advances the IE literature through our incorporation of both exogenous (e.g., foreign market attractiveness) and endogenous (e.g., international entrepreneurial orientation) factors. In addition, we consider other variables, such as foreign market attractiveness and entry mode, which have received relatively little attention in BG studies (Ripolles \& Blesa, 2012). Secondly, we consider three distinct measures of performance, allowing for a more nuanced understanding (Trudgen \& Freeman, 2014); this is important in light of the observed differences in the determinants of the three measures. Thirdly, we undertake a comparison of BGs and firms that have internationalised more traditionally, allowing a delineation of drivers that are distinct to BGs, rather than to internationalising firms in general.

In the following, we discuss our results in more detail, combining the qualitative and quantitative findings, to leverage the benefit from the mixed methods approach (Teddlie \& Tashakkori, 2003).

\subsection{The role of firm and managerial characteristics}

Our model incorporates various attributes of the firm and its managers as determinants of early international performance for BGs. Both of the constructs for international entrepreneurial orientation - Global vision $\mathcal{E}$ perseverance and Innovativeness $\mathcal{E}$ proactiveness - are positively related to Financial and Operational performance for the BGs in our sample, but not Perceived success. While emphasising the value of distinguishing among the various dimensions of performance, these findings resonate with the literature, which highlights the importance of international entrepreneurial orientation for international performance. 
Table 4

Correlation matrix (born globals).

\begin{tabular}{|c|c|c|c|c|c|c|c|c|c|c|c|c|c|c|c|c|c|c|c|}
\hline Constructs & Mean & SD & 1 & 2 & 3 & 4 & 5 & 6 & 7 & 8 & 9 & 10 & 11 & 12 & 13 & 14 & 15 & 16 & 17 \\
\hline 1. Financial performance & 32.53 & 10.26 & & & & & & & & & & & & & & & & & \\
\hline 2. Operational performance & 27.52 & 8.45 & $.69^{* *}$ & & & & & & & & & & & & & & & & \\
\hline 3. Perceived success & 5.23 & 1.20 & $.71^{* *}$ & $.56^{* *}$ & & & & & & & & & & & & & & & \\
\hline $\begin{array}{l}\text { 4. Global vision \& } \\
\text { perseverance }\end{array}$ & 6.18 & .74 & $.30^{* *}$ & $.46^{* *}$ & $.33^{* *}$ & & & & & & & & & & & & & & \\
\hline $\begin{array}{l}\text { 5. Innovativeness \& } \\
\text { proactiveness }\end{array}$ & 5.81 & .83 & $.38^{* *}$ & $.59^{* *}$ & $.35^{* *}$ & $.63^{* *}$ & & & & & & & & & & & & & \\
\hline 6. Product/service quality & 5.93 & .97 & .34 & $.39^{* *}$ & $.36 *$ & $.17^{*}$ & $.36 *$ & & & & & & & & & & & & \\
\hline 7. Customer orientation & 5.64 & .91 & $.37^{* * *}$ & $.53^{* *}$ & $.31^{* *}$ & $.37^{* *}$ & $.63^{* *}$ & $.44^{* *}$ & & & & & & & & & & & \\
\hline 8. Competitor orientation & 5.68 & .85 & $.36 *$ & .42 & $.40^{* *}$ & $.51^{* *}$ & .52 & .22 & $.48^{* *}$ & & & & & & & & & & \\
\hline 9. Learning orientation & 5.80 & .75 & $.31^{* *}$ & $.43^{* *}$ & .26 & $.48^{* *}$ & $.566^{* *}$ & $.23^{* * *}$ & $.62^{* *}$ & $.66^{* *}$ & & & & & & & & & \\
\hline $\begin{array}{l}\text { 10. Importance of } \\
\text { management's personal } \\
\text { contacts for } \\
\text { internationalisation }\end{array}$ & 5.84 & 1.47 & .08 & .11 & .12 & .13 & .11 & .10 & $.27^{* *}$ & $.27^{* * *}$ & $.25^{* *}$ & & & & & & & & \\
\hline $\begin{array}{l}\text { 11. Amount of pre-existing } \\
\text { personal networks for } \\
\text { internationalisation }\end{array}$ & 4.62 & 1.99 & .04 & -.04 & .07 & .06 & -.04 & .10 & .11 & .14 & .08 & $.49^{* *}$ & & & & & & & \\
\hline 12. Niche strategy & 5.53 & 1.00 & .06 & $.37^{* *}$ & .05 & $.33^{* *}$ & $.40^{* *}$ & .14 & $.34 *$ & $.32 *$ & $.36 *$ & .14 & -.02 & & & & & & \\
\hline $\begin{array}{l}\text { 13. Foreign market } \\
\text { attractiveness }\end{array}$ & 5.57 & 1.31 & .00 & $.19^{*}$ & .15 & $.33^{* * *}$ & $.17^{*}$ & .11 & .06 & .09 & .03 & -.05 & $-.19^{*}$ & .01 & & & & & \\
\hline $\begin{array}{l}\text { 14. Internationalisation of } \\
\text { the market }\end{array}$ & 5.75 & 1.15 & $.17^{*}$ & .10 & .14 & $.24^{* *}$ & $.21^{*}$ & $.19^{*}$ & .08 & $.20^{*}$ & .15 & $.18^{*}$ & .08 & .01 & .15 & & & & \\
\hline $\begin{array}{l}\text { 15. Company's annual } \\
\text { gross sales }\end{array}$ & 3.21 & 1.64 & $.32^{* *}$ & $.26^{* *}$ & $.37^{* *}$ & $.20^{*}$ & $.17^{*}$ & .13 & .08 & $.23 *$ & .00 & .13 & .14 & -.09 & .08 & $.32^{* *}$ & & & \\
\hline $\begin{array}{l}\text { 16. Years of doing } \\
\text { international business }\end{array}$ & 7.43 & 2.90 & .15 & .06 & .02 & -.05 & .06 & .06 & .10 & .02 & -.02 & .10 & .03 & .09 & $-.17^{*}$ & -.15 & .13 & & \\
\hline 17. Manufacturing dummy & .29 & .45 & -.03 & .03 & .04 & .12 & .05 & -.03 & -.01 & .00 & .02 & -.10 & -.09 & .04 & .07 & -.10 & -.07 & $-.20^{*}$ & \\
\hline 18. Export entry & .71 & .46 & $.17^{*}$ & .15 & .10 & -.05 & .07 & .05 & .15 & -.01 & -.03 & .07 & -.04 & .04 & .01 & $.23^{* *}$ & .06 & -.07 & .10 \\
\hline
\end{tabular}

${ }^{*} p<.05$; two-tailed test.

$p<.01$; two-tailed test. 
Table 5

Correlation matrix (non-born globals).

\begin{tabular}{|c|c|c|c|c|c|c|c|c|c|c|c|c|c|c|c|c|c|c|c|}
\hline Constructs & Mean & SD & 1 & 2 & 3 & 4 & 5 & 6 & 7 & 8 & 9 & 10 & 11 & 12 & 13 & 14 & 15 & 16 & 17 \\
\hline 1. Financial performance & 23.95 & 9.60 & & & & & & & & & & & & & & & & & \\
\hline 2. Operational performance & 21.58 & 8.62 & $.69^{* *}$ & & & & & & & & & & & & & & & & \\
\hline 3. Perceived success & 4.53 & 1.33 & .62 & .52 & & & & & & & & & & & & & & & \\
\hline $\begin{array}{l}\text { 4. Global vision \& } \\
\text { perseverance }\end{array}$ & 4.88 & 1.40 & $.33^{* *}$ & $.53^{* *}$ & $.34^{* *}$ & & & & & & & & & & & & & & \\
\hline $\begin{array}{l}\text { 5. Innovativeness \& } \\
\text { proactiveness }\end{array}$ & 5.47 & .86 & $.17^{*}$ & $.36^{* *}$ & $.19^{*}$ & $.55^{* *}$ & & & & & & & & & & & & & \\
\hline 6. Product/service quality & 5.65 & .90 & $.36^{* *}$ & $.36 *$ & $.45^{* *}$ & .34 & $.35^{* *}$ & & & & & & & & & & & & \\
\hline 7. Customer orientation & 5.59 & .88 & .08 & $.29^{* *}$ & .09 & $.26^{* *}$ & $.52^{* *}$ & $.17^{*}$ & & & & & & & & & & & \\
\hline 8. Competitor orientation & 5.46 & .95 & .04 & .22 & .01 & $.25^{* *}$ & $.40^{* *}$ & .03 & .64 & & & & & & & & & & \\
\hline 9. Learning orientation & 5.65 & .81 & $.21 *$ & $.35^{* *}$ & $.21^{* *}$ & $.41^{* *}$ & .50 & .32 & $.58^{* *}$ & $.57^{* *}$ & & & & & & & & & \\
\hline $\begin{array}{l}\text { 10. Importance of } \\
\text { management's personal } \\
\text { contacts for } \\
\text { internationalisation }\end{array}$ & 5.58 & 1.43 & .12 & .09 & .06 & .07 & .07 & -.02 & .00 & .13 & .01 & & & & & & & & \\
\hline $\begin{array}{l}\text { 11. Amount of pre-existing } \\
\text { personal networks for } \\
\text { internationalisation }\end{array}$ & 4.43 & 1.93 & $.17^{*}$ & .11 & .14 & .07 & -.02 & .02 & .03 & .13 & .09 & $.32^{* *}$ & & & & & & & \\
\hline 12. Niche strategy & 4.97 & 1.26 & .34 & $.51^{* *}$ & $.29^{* *}$ & $.50^{* *}$ & $.43^{* *}$ & $.39^{* *}$ & $.20^{*}$ & $.19^{*}$ & $.33^{* *}$ & .15 & -.04 & & & & & & \\
\hline $\begin{array}{l}\text { 13. Foreign market } \\
\text { attractiveness }\end{array}$ & 4.46 & 1.78 & $.33^{* *}$ & .32 & $.24^{* *}$ & $.45^{* *}$ & $.25^{* *}$ & $.30^{* *}$ & .07 & .00 & .07 & .07 & -.08 & $.37^{* *}$ & & & & & \\
\hline $\begin{array}{l}\text { 14. Internationalisation of } \\
\text { the market }\end{array}$ & 5.26 & 1.26 & .13 & .14 & -.05 & $.18^{*}$ & $.22^{* *}$ & .02 & $.20^{* * *}$ & $.20^{* *}$ & $.19^{*}$ & $.17^{*}$ & $.16^{*}$ & .08 & .07 & & & & \\
\hline $\begin{array}{l}\text { 15. Company's annual } \\
\text { gross sales }\end{array}$ & 3.19 & 1.68 & .03 & -.04 & .09 & .08 & .11 & .00 & .10 & $.24^{* *}$ & .10 & $-.18^{*}$ & .02 & $-.16^{*}$ & .01 & -.01 & & & \\
\hline $\begin{array}{l}\text { 16. Years of doing } \\
\text { international business }\end{array}$ & 6.73 & 3.05 & -.10 & -.14 & .08 & -.04 & -.09 & -.04 & .04 & .04 & -.01 & -.07 & $.19^{*}$ & -.10 & -.06 & .01 & $.19^{*}$ & & \\
\hline 17. Manufacturing dummy & .31 & .47 & .23 & .24 & $.17^{*}$ & .07 & .06 &, 15 & .02 & -.13 & -.04 & .11 & -.02 & .14 & .14 & -.06 & .00 & .07 & \\
\hline $\begin{array}{l}\text { 18. Export entry } \\
\text { mode dummy }\end{array}$ & .64 & .48 & .00 & .04 & .02 & -.02 & .01 & .10 & .00 & -.04 & .01 & .06 & .00 & .02 & .03 & .00 & .01 & .08 & .19 \\
\hline
\end{tabular}

${ }^{*} p<.05$; two-tailed test

$p<.01$; two-tailed test 
Table 6

Regression estimates for international performance.

\begin{tabular}{|c|c|c|c|c|c|c|}
\hline & \multicolumn{3}{|l|}{ Born globals } & \multicolumn{3}{|c|}{ Non-born globals } \\
\hline & $\begin{array}{l}\text { Financial } \\
\text { performance }\end{array}$ & $\begin{array}{l}\text { Operational } \\
\text { performance }\end{array}$ & $\begin{array}{l}\text { Perceived } \\
\text { success }\end{array}$ & $\begin{array}{l}\text { Financial } \\
\text { performance }\end{array}$ & $\begin{array}{l}\text { Operational } \\
\text { performance }\end{array}$ & $\begin{array}{l}\text { Perceived } \\
\text { success }\end{array}$ \\
\hline Intercept & $-15.90(8.89)^{\dagger}$ & $-25.94(6.20)^{* *}$ & $-.98(1.08)$ & $-5.01(7.76)$ & $-8.40(6.26)$ & $-.05(1.09)$ \\
\hline Global vision \& perseverance (H1) & $2.57(1.52)^{\dagger}$ & $2.29(1.09)^{*}$ & $.23(.18)$ & $.14(.80)$ & $1.80(.66)^{* *}$ & $.26(.12)^{*}$ \\
\hline Innovativeness \& proactiveness (H1) & $2.53(1.51)^{\dagger}$ & $2.12(1.08)^{\dagger}$ & $.10(.18)$ & $-1.42(1.33)$ & $-1.44(1.07)$ & $-.20(.18)$ \\
\hline Product/service quality $(\mathrm{H} 2)$ & $2.80(.88)^{* *}$ & $1.94(.72)^{* * *}$ & $.39(.11)^{* * *}$ & $2.06(.96)^{*}$ & $.79(.78)$ & $.50(.13)^{*+4}$ \\
\hline Customer orientation (H3) & $-.94(1.32)$ & $1.02(.92)$ & $-.07(.16)$ & $-.37(1.31)$ & $1.02(1.02)$ & $-.02(.17)$ \\
\hline Competitor orientation (H3) & $2.50(1.30)^{\dagger}$ & $.97(.91)$ & $.40(.15)^{*}$ & $-.83(1.19)$ & $.67(.95)$ & $-.17(.17)$ \\
\hline Learning orientation $(\mathrm{H} 4)$ & $1.52(1.65)$ & $.78(1.16)$ & $.02(.20)$ & $2.22(1.39)$ & $.90(1.08)$ & $.24(.19)$ \\
\hline $\begin{array}{l}\text { Importance of management's } \\
\text { personal contacts for } \\
\text { internationalisation (H5) }\end{array}$ & $-.30(.61)$ & $-.02(.43)$ & $-.01(.07)$ & $.02(.64)$ & $-.12(.48)$ & $.12(.09)$ \\
\hline $\begin{array}{l}\text { Amount of pre-existing personal } \\
\text { networks for internationalisation (H5) }\end{array}$ & $-.53(.46)$ & $-.41(.32)$ & $-.01(.06)$ & $.98(.46)^{*}$ & $.54(.36)$ & $.05(.06)$ \\
\hline Niche strategy (H6) & $-2.72(.94)^{* *}$ & $.56(.61)$ & $-.14(.10)$ & $1.24(.77)$ & $1.86(.63)^{* *}$ & $.03(.11)$ \\
\hline Foreign market attractiveness (H7) & $-.69(.70)$ & $-.16(.48)$ & $.036(.08)$ & $1.03(.51)^{*}$ & $.24(.41)$ & $.06(.07)$ \\
\hline Internationalisation of the market (H8) & $-.56(.81)$ & $-.85(.56)$ & $-.05(.10)$ & $.73(.67)$ & $.02(.54)$ & $-.14(.09)$ \\
\hline Company's annual gross sales & $1.15(.55)^{*}$ & $.82(.37)^{*}$ & $.19(.06)^{* * *}$ & $.64(.49)$ & $.00(.40)$ & $.10(.07)$ \\
\hline Years of doing international business & $.41(.29)$ & $.04(.21)$ & $.02(.04)$ & $-.47(.26)^{\dagger}$ & $-.47(.20)^{*}$ & $.04(.04)$ \\
\hline Manufacturing dummy & $-.82(1.74)$ & $-1.15(1.24)$ & $.03(.21)$ & $4.36(1.75)^{*}$ & $3.72(1.40)^{* *}$ & $.11(.25)$ \\
\hline Export entry mode dummy & $4.09(1.83)^{*}$ & $2.16(1.24)^{\dagger}$ & $.33(.22)$ & $-1.36(1.58)$ & $-.25(1.26)$ & $-.12(.22)$ \\
\hline$n$ & 118 & 117 & 127 & 132 & 129 & 135 \\
\hline$R^{2}\left(\operatorname{adj} . R^{2}\right)$ & $.44(.36)$ & $.57(.51)$ & $.40(.32)$ & $.31(.22)$ & $.44(.36)$ & $.34(.25)$ \\
\hline Max. VIF & 2.84 & 2.86 & 2.76 & 2.35 & 2.36 & 2.36 \\
\hline
\end{tabular}

${ }^{\dagger} p<.10$

${ }^{*} p<.05$.

$p<.01$.

Standard errors in parentheses.

Hypotheses pertain to born global sample.

The concept of perseverance is an entrepreneurial characteristic that emerged strongly from the interviews. Baum and Locke (2004) defined perseverance as a necessary condition for success in starting and running entrepreneurial ventures, and Markman, Baron, and Balkin (2005) and Van Gelderen (2012) discussed the importance of entrepreneurs' remaining true to their goals even in extremely difficult and adverse conditions. Perseverance, which can pertain to the perception of either control over adversity or responsibility/accountability for the outcome of adversity (Markman et al., 2005), has its foundations in the entrepreneur's personality traits literature (e.g., Boyd \& Vozikis, 1994; Wood \& Bandura, 1989) and is linked to the concept of self-efficacy (Chen, Greene, \& Crick, 1998). Freeman, Deligonul, and Cavusgil (2013) found that BGs persevered by maintaining continued contact with foreign networks in spite of adverse environmental conditions, thus taking a long-term view of their relationships. The concept of perseverance is aptly captured in our interviews by the manager of MFG1, who stated that "... there is no reason to sprint a marathon." Similarly, the manager of MFG2 emphasised the importance of perseverance for superior performance:

And perseverance - very, very important. Without perseverance we would have given up a long time ago, because it is very, very hard to break into international markets. But it's got to be a longterm plan.

Our incorporation of this attribute advances the IE literature, which has tended to focus on the three dimensions of proactiveness, risk-taking and innovativeness in the context of entrepreneurial orientation (e.g., Kuivalainen et al., 2007).

Comparison of BGs and traditional internationalisers provides some additional insights. For the non-BG sample, Global vision $\mathcal{E}$ perseverance is related to Operational performance and Perceived success, but not Financial performance, suggesting that, for non-BGs, these attributes are associated more with "softer" performance criteria, such as the firm's international reputation. It may be that global vision and perseverance are important prerequisites for these firms to access international markets, for example, by improving the company's global reach and through more effective development of new products for other markets, but may not necessarily result in higher financial performance. In addition, Innovativeness $\mathcal{E}$ proactiveness is not a significant performance driver for non-BGs, which may reflect a more reactive approach to internationalisation, relative to BGs. This suggests that innovative and proactive postures may be specific characteristics necessary for BGs to compete successfully overseas. These findings also provide support for separate analysis of the components of international entrepreneurial orientation, as proposed by Frishammar and Andersson (2009), Morgan and Strong (2003), and Dai, Maksimov, Gilbert, and Fernhaber (2014).

The second firm and managerial characteristic we consider is Product/service quality, which is positively associated with all three measures of international performance for the BG sample (and two of the three for non-BGs). These results are consistent with previous findings identifying quality as a key competitive advantage (Rennie, 1993), and the importance of a focus on quality for engendering superior international performance (Knight \& Cavusgil, 2004; Larimo, 2006) among BGs. The qualitative data also support these findings; the manager of MFG2 emphasised the importance of a "decent product to sell", and recommended that "if you haven't got a good product to start with, do not even bother [to go international]."

We operationalise the third characteristic, Market orientation, using two factors: Customer orientation and Competitor orientation. While we find no marginal significance associated with the former, Competitor orientation is associated with stronger Financial performance and Perceived success for the BG sample. Consistent with extant research on export performance (e.g., Thirkell \& Dau, 1998) and born globals (Kocak \& Abimbola, 2009), this finding can be linked to the importance of competitor analysis for business performance in the strategic management literature (Chen, 1996). Our results are in line with Ruokonen, Nummela, Puumalainen, and Saarenketo (2008) who connected the concept 
of market orientation with networks and argued that interfunctional co-ordination (Narver \& Slater, 1990) should be replaced by value-network co-ordination when defining market orientation in the context of SMEs.

Our interviews also highlighted the importance of strong competitor orientation for international performance. The manager of FOOD mentioned that the company is actively monitoring its competitors' strategies and noted that:

We don't ever put our product on a boat and wave good-bye to it. We're very much there. You can't do it from sitting here in New Zealand. You have to be there. And that's the same with any international market is that you need to be there and be seen.

In contrast, no significant relationship between market orientation and performance is identified for the non-BG sample. It may be that non-BGs are more likely to follow their domestic clients abroad (Bell, McNaughton, Young, \& Crick, 2003), reducing the relevance of a strong market orientation for performance.

Our fourth firm and managerial characteristic, Learning orientation, displays no marginal relationship with international performance for either the BG or non-BG sample. While this contradicts earlier findings for both small and larger firms (Baker \& Sinkula, 1999) and in the context of BGs (Jantunen et al., 2008), our qualitative findings may shed light on this issue. The manager of ICT1 mentioned that the firm adopted a rather unstructured approach to learning and noted that "we didn't put much emphasis on HR, and learning, and continued learning". Marginal to the other variables in the models, the adoption of a learning orientation may be related to outcomes other than financial and operational firm performance, such as increased employee motivation and job satisfaction (e.g., Egan, Yang, \& Bartlett, 2004; Joo \& Lim, 2009). Our result may also reflect the difficulty associated with separating learning from other aspects of doing business for these young and dynamic firms, who are regularly faced with situations that are new and offer learning opportunities. This is consistent with some recent work that suggests the possibility that learning plays a mediating role, between entrepreneurial orientation and innovation (Kocak \& Abimbola, 2009) and knowledge learning and the degree of international engagement and commitment (Zou \& Ghauri, 2010).

\subsection{The role of networks}

Two variables pertaining to management's personal networks are included in our models, to consider both the importance and extent of such networks for BGs' international performance. The quantitative modelling provides no support for a relationship between management's personal networks and international performance for BGs, and limited support for non-BGs. While these results are inconsistent with many previous studies that have highlighted the key role of personal networks for successful internationalisation by BGs (e.g., Freeman et al., 2006; Manolova, Manev, \& Gyoshev, 2010), our interview results provide some clarification. The manager of ICT1 commented on the importance of customer engagement and effective relationship management:

I don't think it was the personal networks. I think it was more the experience of knowing how to engage with these big companies. I mean you just got to know how to approach the companies like an $H P$, and a Dell, and a Panasonic and a Sony, and an LG and a Samsung. You know those are big companies; they're complex companies.

Thus, our findings are more in line with Thai and Chong (2008: 95), who concluded that pre-existing personal networks are not necessarily a "must-have" for BGs. It is interesting to note that the interviews revealed no discernable distinction between B2B and
B2C firms, with respect to their perspectives on the relationship between networks and performance.

\subsection{The role of business strategy}

The adoption of niche strategies has been viewed as particularly relevant to BGs (Bell et al., 2003; Chetty \& Campbell-Hunt, 2004), and for broader export performance (Zucchella \& Palamara, 2006). However, our modelling provides contrary evidence for the BG sample. A potential explanation for this surprising finding comes from the manager of MFG2, who noted that the international strategy of born globals is multi-faceted and includes different strategic approaches:

Some of it [international strategy] is driven by cost reduction, some of it is driven by just having the need for local input to make it viable because of the long lead times at New Zealand and the funding costs of shipping a product for 60 or 70 days across the water.

McDougall and Robinson (1990) found evidence that, for new ventures entering new markets, aggressive growth strategies on a larger scale may yield better financial and market performance than niche strategies. It may be that BGs succeed not necessarily by product specialisation, but by aiming for breadth in product lines and broader appeal, in order to achieve critical mass. In an interesting contrast, our modelling suggests that a more niche strategy was positively related to operational performance for the non-BG sample.

\subsection{The role of the external environment}

Compared to entrepreneurial and organisational characteristics, the relationship between the external environment and performance for BGs has received limited research attention (Aspelund et al., 2007). We examine two key aspects of the external environment - Foreign market attractiveness and Internationalisation of the market - but find no empirical support for their hypothesised relationships with performance in the BG sample, marginal to the other variables in the models. The market attractiveness result, while inconsistent with previous studies in the export literature (e.g., Madsen, 1989), is illuminated by our interview findings. As the manager of MFG2 noted:

.. the American market is attractive because it's so big. That is so massive but it is extremely competitive. One of the things with a big westernised market is that it is very, very competitive.

For BGs, internal factors may be more important than external market factors for explaining variations in international performance. In contrast, for the non-BG sample, a positive relationship was found between foreign market attractiveness and financial performance, which is more consistent with the export literature that has a stronger focus on more traditionally internationalising firms. With respect to internationalisation of the market, our results suggest that this may be more of an important condition for doing international business, rather than a driver of performance. The findings from the qualitative interviews highlighted the potential opportunities of highly internationalised markets. The manager of MFG2 commented that

it [internationalisation of the market] means that we are pioneering and trying to break new ground so we're actually trying to create the rules of international business around our industry.

Table 7 summarises the key findings from the qualitative and quantitative analyses and the implications of the study, comparing the BG and non-BG samples. 
Table 7

Summary of key findings and implications.

\begin{tabular}{|c|c|c|c|c|}
\hline \multirow[t]{2}{*}{ Construct } & \multirow[t]{2}{*}{ Qualitative interview findings } & \multicolumn{2}{|c|}{ Quantitative survey results } & \multirow[t]{2}{*}{ Summary } \\
\hline & & BG sample & Non-BG sample & \\
\hline $\begin{array}{l}\text { Global vision \& } \\
\text { perseverance }(\mathrm{H} 1) \\
\text { Innovativeness \& } \\
\quad \text { proactiveness (H1) }\end{array}$ & $\begin{array}{l}\text { Strong support, strong theme } \\
\text { Don't sprint a marathon! (MFG1) } \\
\text { I'm following a passion. I'm following a } \\
\text { dream. And everything that I'm doing you } \\
\text { can look at it from a, you know, textbook } \\
\text { point of view. It's just something that's really } \\
\text { just coming natural to me as a CEO... I'm an } \\
\text { entrepreneur at heart. It's in my blood, it's in } \\
\text { my family. (MFG1) }\end{array}$ & $\begin{array}{l}\text { Financial: }+ \\
\text { Operational: }+ \\
\text { Perceived success: NS } \\
\text { Financial: }+ \\
\text { Operational: }+ \\
\text { Perceived success: NS }\end{array}$ & $\begin{array}{l}\text { Financial: NS } \\
\text { Operational: }+ \\
\text { Perceived success: }+ \\
\text { Financial: NS } \\
\text { Operational: NS } \\
\text { Perceived success: NS }\end{array}$ & $\begin{array}{l}\text { Key role of international } \\
\text { entrepreneurial orientation as } \\
\text { driver of financial and } \\
\text { operational performance for BGs } \\
\text { Perseverance as important } \\
\text { construct } \\
\text { Innovativeness and } \\
\text { proactiveness as performance } \\
\text { antecedents uniquely for BGs }\end{array}$ \\
\hline $\begin{array}{c}\text { Product/service } \\
\text { quality }(\mathrm{H} 2)\end{array}$ & $\begin{array}{l}\text { Strong support } \\
\text { Quality. Absolutely. Quality is very, very } \\
\text { important for us. Quality in the product and } \\
\text { quality in the packaging, everything. You } \\
\text { know that it all fits together. (FOOD) }\end{array}$ & $\begin{array}{l}\text { Financial: }+ \\
\text { Operational: }+ \\
\text { Perceived success: }+\end{array}$ & $\begin{array}{l}\text { Financial: }+ \\
\text { Operational: NS } \\
\text { Perceived success: + }\end{array}$ & $\begin{array}{l}\text { Critical role of product/service } \\
\text { quality for international } \\
\text { performance of BGs and non-BGs }\end{array}$ \\
\hline $\begin{array}{l}\text { Customer } \\
\text { orientation (H3) } \\
\text { Competitor } \\
\text { orientation (H3) }\end{array}$ & $\begin{array}{l}\text { Strong support } \\
\text { Role of customer engagement skills, } \\
\text { visiting international markets, "being } \\
\text { there" in the markets } \\
\text { I think it was more the experience of knowing } \\
\text { how to engage with these big companies... } \\
\text { It's being in our markets, you know, talking to } \\
\text { our customers and building those } \\
\text { relationships. (ICT1) }\end{array}$ & $\begin{array}{l}\text { Financial: NS } \\
\text { Operational: NS } \\
\text { Perceived success: NS } \\
\text { Financial: + } \\
\text { Operational: NS } \\
\text { Perceived success: + }\end{array}$ & $\begin{array}{l}\text { Financial: NS } \\
\text { Operational: NS } \\
\text { Perceived success: NS } \\
\text { Financial: NS } \\
\text { Operational: NS } \\
\text { Perceived success: NS }\end{array}$ & $\begin{array}{l}\text { Customer engagement skills, } \\
\text { visiting international markets, } \\
\text { "being there" in markets as key } \\
\text { themes from interviews for BGs } \\
\text { Focus on competitors important } \\
\text { for financial performance and } \\
\text { perceived success of BGs } \\
\text { Competitor orientation as } \\
\text { specific performance antecedent } \\
\text { for BGs }\end{array}$ \\
\hline $\begin{array}{l}\text { Learning } \\
\quad \text { orientation }(\mathrm{H} 4)\end{array}$ & $\begin{array}{l}\text { Some support } \\
\text { We're starting to put much more emphasis on } \\
\text { professional development and learning and } \\
\text { process. I think while we were still a start-up } \\
\text { it was about just using people's experience } \\
\text { and now we're also looking at growing } \\
\text { people. (ICT1) }\end{array}$ & $\begin{array}{l}\text { Financial: NS } \\
\text { Operational: NS } \\
\text { Perceived success: NS }\end{array}$ & $\begin{array}{l}\text { Financial: NS } \\
\text { Operational: NS } \\
\text { Perceived success: NS }\end{array}$ & $\begin{array}{l}\text { Learning orientation may not } \\
\text { have direct relationship with } \\
\text { financial and operational } \\
\text { performance of BGs, but may be } \\
\text { related to other outcomes, such } \\
\text { as employee motivation or job } \\
\text { satisfaction }\end{array}$ \\
\hline $\begin{array}{l}\text { Importance of } \\
\text { management's } \\
\text { personal contacts for } \\
\text { internationalisation } \\
\text { (H5) }\end{array}$ & $\begin{array}{l}\text { Mixed support } \\
\text { Also, through a couple of our senior staff, } \\
\text { their actual networks and business have been } \\
\text { very, very useful in developing new } \\
\text { relationships from their past careers. So, for }\end{array}$ & $\begin{array}{l}\text { Financial: NS } \\
\text { Operational: NS } \\
\text { Perceived success: NS }\end{array}$ & $\begin{array}{l}\text { Financial: NS } \\
\text { Operational: NS } \\
\text { Perceived success: NS }\end{array}$ & $\begin{array}{l}\text { Personal networks not "must- } \\
\text { have" for BGs } \\
\text { Personal networks not } \\
\text { significant driver of international } \\
\text { performance for BGs }\end{array}$ \\
\hline $\begin{array}{l}\text { Amount of pre-existing } \\
\text { personal networks for } \\
\text { internationalisation } \\
\text { (H5) }\end{array}$ & $\begin{array}{l}\text { example, I've got a guy that was running a US } \\
\text { operation and he used to live in Japan for } \\
12 \text { years. He's actually networked into a lot of } \\
\text { business into Japan so he's got contacts to } \\
\text { some of the Iapanese companies. (MFG2) }\end{array}$ & $\begin{array}{l}\text { Financial: NS } \\
\text { Operational: NS } \\
\text { Perceived success: NS }\end{array}$ & $\begin{array}{l}\text { Financial: }+ \\
\text { Operational: NS } \\
\text { Perceived success: NS }\end{array}$ & $\begin{array}{l}\text { Personal networks more } \\
\text { important for non-BGs as } \\
\text { antecedent of financial } \\
\text { performance }\end{array}$ \\
\hline
\end{tabular}

Not really. I wouldn't say personal networks have gotten us any business. It wasn't preexisting networks. We didn't get to where we are through established networks. (ICT1)

Niche strategy (H6)

Some support and some contradiction Blue ocean strategy

So we've ignored the traditional markets where the entrenched competitors are and we've gone after the new markets, and they are the high-growth markets. Going for new markets, going for markets with inflection points driving to first time use of our products. (ICT1)

Foreign market attractiveness (H7)

Some support

In all the markets that we are in, there is huge potential because there isn't a lot around, particularly where our product is concerned, there is nothing like it around. (FOOD)

Internationalisation of the market (H8)
Some support

E-learning is an international industry. It allows institutions worldwide to implement solutions. I think it is extremely important [for international performance]. We developed partnerships locally and then internationally. There are greater opportunities to partner. (EDUC)
Financial: -

Operational: NS

Perceived success: NS

Operational: +

Perceived success: NS

Financial: NS

Operational: NS

Perceived success: NS

Financial: +

Operational: NS

Perceived success: NS

Financial: NS

Operational: NS

Perceived success: NS
Financial: NS

Operational: NS

Perceived success: NS
BGs may adopt multi-faceted approach to strategy, and may not only aim at product specialisation, but also at bigger market to achieve "critical mass" Niche strategy as specific operational performance antecedent for non-BGs

External market environment may be less relevant in explaining performance variations of born globals compared to internal factors (e.g., product/service quality)

Internationalisation of the market may provide important context for doing international business, but not antecedent of international performance for BGs and non-BGs

\footnotetext{
+ : positive relationship.

- : negative relationship.

NS: not significant.
} 


\section{Managerial relevance}

Our results highlight the importance of a global vision, suggesting that BG managers may benefit from viewing the world, rather than the domestic market, as the marketplace. Interviewees highlighted the importance of positioning the firm as a "global company", as opposed to an "exporter", as these strategic positions convey different signals to potential customers. The manager of ICT1 noted that "it limits the company's thinking if they think of themselves as an exporter". In addition, perseverance appears to play an important role in international performance; the marathon analogy used by the manager of MFG1 illustrates that success requires commitment and a long-term perspective. The concepts of positioning as a global company and perseverance have received relatively little attention in the BG literature to date. Our findings regarding these entrepreneurial qualities contribute to Keupp and Gassmann's call (2009) to focus on the entrepreneurship aspect of IE. Our study also builds on Jones et al. (2011: 643), who argued that "we need a greater understanding of entrepreneurs and their teams as they relate to entrepreneurial internationalization".

We also find strong support for the notion that a focus on product/service quality is associated with stronger international performance for these small firms. The qualitative evidence provides additional insights, as the interviewed BG firms compete primarily on quality, rather than on price. In addition, our finding regarding competitor orientation suggests that BG managers would do well to undertake careful analysis of their competitors' strengths and weaknesses, and evaluate the competition's strategies on a regular basis. Given that previous BG studies have not tended to focus on the role of competitor orientation, this empirical evidence helps to advance our understanding of international performance drivers for BGs. Our findings also highlight that how BGs choose to approach foreign markets at the start has ramifications for performance, which is consistent with the conclusion of Jones and Young (2009) regarding the importance of entry mode.

In terms of contributions to policymakers, visits to foreign markets and engaging with customers were important themes that emerged from the interviews. Governments may assist firms by providing market intelligence, logistical support for trade fair participation, and services such as translation that may function as "door-openers" to international markets.

Overall, the findings of our study suggest that BGs have some international performance drivers that differ from those of more traditionally internationalising companies. In addition, internal factors, such as product/service quality, tend to be more relevant than external attributes for explaining the variation in BG performance.

\section{Limitations of the study and directions for future research}

Like all empirical studies, this one is subject to limitations. In addition to the potential for common method bias, due to single responses from each firm, the survey responses may have been affected by respondents' memory bias. Managers were asked questions related to their companies' early international performance. Thus, responses were based on past events, and dependent on the managers' accurate recollection. Although our sampling frame included only young firms, to minimise the effect of memory bias, this does represent a potential limitation, as does the geographic location of the sample firms. We have examined firms in Australia and New Zealand, which are two small, open economies (SMOPECs) that are geographically isolated. While our findings may not be directly applicable to firms whose home countries are larger or in closer proximity to other target markets, the literature provides ample evidence that SMOPECs' constrained domestic market size and permeable borders create excellent conditions for the development of born global firms (e.g., Gabrielsson et al., 2012), making this context important to understand for the study of BGs. Still, we echo the recommendation of Jones et al. (2011), regarding the need for more crosscultural research on BGs from a variety of home countries.

As outlined earlier, the BG performance field is relatively young, leaving considerable scope for future research. One such area pertains to the issue of survival for BGs. Interviewees emphasised the importance of survival; as the manager of ICT2 stated, "The first rule of business is to stay in business." Future studies could examine the factors that enable BGs to survive, building on Mudambi and Zahra (2007), and Sleuwaegen and Onkelinx (2014), and undertake comparisons between survivors and non-survivors.

In addition, there is considerable scope for future research to consider the interaction between industry and BG performance. While much of the BG literature to date has focused on firms in high-technology businesses, the firms in both the qualitative and quantitative aspects of our study represent a broad range of industries, from soft services to high-technology manufacturing. Our sample size did not allow for the use of fine-grained industry categorisations, which leaves many interesting questions to be addressed in future research, including distinctions within the manufacturing (e.g., technological level) and service (e.g., knowledge intensity) sectors.

This study is grounded in the RBV and network perspective on internationalisation, which have been employed in previous BG research (e.g., Knight \& Cavusgil, 2004). Future research may also adopt other conceptual frameworks, such as institutional theory (North, 1990). Under the view that institutions are the "rules of the game in a society" (North, 1990: 3), the roles of government, regulations, and informal institutions (e.g., culture) in both home and foreign markets provide relevant scope to examine in future studies, thus advancing our understanding of the drivers of born global performance.

\section{Acknowledgements}

The authors would like to thank senior editor Professor Peter Liesch and two anonymous reviewers for their valuable comments. This work was supported by the 2015 Hannam University Research Fund.

\section{References}

Al-Laham, A., \& Souitaris, V. (2008). Network embeddedness and new-venture internationalization: Analyzing international linkages in the German biotech industry. Journal of Business Venturing, 23(5): 567-586.

Andersson, S. (2000). The internationalization of the firm from an entrepreneurial perspective. International Studies of Management E Organization, 30(1): 63-92.

Andersson, S., \& Wictor, I. (2003). Innovative internationalization in new firms: Born globals - The Swedish case. Journal of International Entrepreneurship, 1(3): 249-276.

Aspelund, A., Madsen, T. K., \& Moen, O. (2007). A review of the foundation, international marketing strategies, and performance of international new ventures. European Journal of Marketing, 41(11/12): 1423-1448.

Autio, E., Sapienza, H. J., \& Almeida, J. G. (2000). Effects of age at entry, knowledge intensity, and imitability on international growth. Academy of Management Journal, 43(5): 909-924.

Baker, W. E., \& Sinkula, J. M. (1999). The synergistic effect of market orientation and learning orientation on organizational performance. Journal of the Academy of Marketing Science, 27(4): 411-427.

Baldauf, A., Cravens, D. W., \& Wagner, U. (2000). Examining determinants of export performance in small open economies. Journal of World Business, 35(1): 65-79.

Barney, J. (1991). Firm resources and sustained competitive advantage. Journal of Management, 17(1): 99-120.

Baum, J. R., \& Locke, E. A. (2004). The relationship of entrepreneurial traits, skill, and motivation to subsequent venture growth. Journal of Applied Psychology, 89(4): 587-598.

Bazeley, P. (2007). Qualitative data analysis with NVivo. London: Sage.

Bazeley, P. (2008). Mixed methods in management research. In R. Thorpe \& R. Holt (Eds.), The SAGE dictionary of qualitative management research (pp. 133-136). London: Sage. 
Bell, J., McNaughton, R., \& Young, S. (2001). Born-again global firms: An extension to the born global phenomenon. Journal of International Management, 7(3): 173-189.

Bell, J., McNaughton, R., Young, S., \& Crick, D. (2003). Towards an integrative model of small firm internationalisation. Journal of International Entrepreneurship, 1(4): 339-362.

Blomstermo, A., Eriksson, K., Lindstrand, A., \& Sharma, D. D. (2004). The perceived usefulness of network experiential knowledge in the internationalizing firm. Journal of International Management, 10(3): 355-373.

Boyd, N. G., \& Vozikis, G. S. (1994). The influence of self-efficacy on the development of entrepreneurial intentions and actions. Entrepreneurship: Theory and Practice, 18(4): 63-90.

Brouthers, K. D. (2002). Institutional, cultural and transaction cost influences on entry mode choice and performance. Journal of International Business Studies, 33(2): 203-222.

Brouthers, K. D., \& Nakos, G. (2004). SME entry mode choice and performance: A transaction cost perspective. Entrepreneurship: Theory and Practice, 28(3): 229-247.

Buzzell, R. D., \& Gale, B. T. (1987). The PIMS principles: Linking strategy to performance. New York: The Free Press.

Cavusgil, S. T., \& Zou, S. M. (1994). Marketing strategy-performance relationship: An investigation of the empirical link in export ventures. Journal of Marketing, 58(1): $1-21$.

Chen, C. C., Greene, P. G., \& Crick, A. (1998). Does entrepreneurial self-efficacy distinguish entrepreneurs from managers? Journal of Business Venturing, 13(4): 295-316.

Chen, M.-J. (1996). Competitor analysis and interfirm rivalry: Toward a theoretical integration. Academy of Management Review, 21(1): 100-134.

Chenhall, R. H., \& Langfield-Smith, K. (2007). Multiple perspectives of performance measures. European Management Journal, 25(4): 266-282.

Chetty, S., \& Agndal, H. (2007). Social capital and its influence on changes in internationalization mode among small and medium-sized enterprises. Journal of International Marketing, 15(1): 1-29.

Chetty, S., \& Agndal, H. (2008). The role of interorganizational networks and interpersonal networks in an industrial district. Regional Studies, 42(2): 175-187.

Chetty, S., \& Campbell-Hunt, C. (2004). A strategic approach to internationalization: A traditional versus a "born-global" approach. Journal of International Marketing, 12(1): $57-81$

Chetty, S., \& Stangl, L. M. (2010). Internationalization and innovation in a network relationship context. European Journal of Marketing, 44(11/12): 1725-1743.

Cho, H.-J., \& Pucik, V. (2005). Relationship between innovativeness, quality, growth, profitability, and market value. Strategic Management Journal, 26(6): 555-575.

Ciabuschi, F., Perna, A., \& Snehota, I. (2012). Assembling resources when forming a new business. Journal of Business Research, 65(2): 220-229.

Conner, K. R. (1991). A historical comparison of resource-based theory and five schools of thought within industrial organization economics: Do we have a new theory of the firm? Journal of Management, 17(1): 121-154.

Coviello, N. (2006). The network dynamics of international new ventures. Journal of International Business Studies, 37(5): 713-731.

Coviello, N., \& Jones, M. V. (2004). Methodological issues in international entrepreneurship research. Journal of Business Venturing, 19(4): 485-508.

Coviello, N. E., McDougall, P. P., \& Oviatt, B. M. (2011). The emergence, advance and future of international entrepreneurship research. Journal of Business Venturing, 26(6): 625-631.

Coviello, N., \& Munro, H. (1997). Network relationships and the internationalisation process of small software firms. International Business Review, 6(4): 361-386.

Covin, J. G., \& Slevin, D. P. (1989). Strategic management of small firms in hostile and benign environments. Strategic Management Journal, 10(1): 75-87.

Covin, J. G., \& Miller, D. (2014). International entrepreneurial orientation: Conceptual considerations, research themes, measurement issues, and future research directions. Entrepreneurship Theory and Practice, 38(1): 11-44.

Crick, D. (2009). The internationalisation of born global and international new venture SMEs. International Marketing Review, 26(4/5): 453-476.

Crick, D., \& Chaudry, S. (2010). An investigation into UK-based Asian entrepreneurs' perceived competitiveness in overseas markets. Entrepreneurship \& Regional Development, 22(1): 5-23.

Crick, D., \& Jones, M. V. (2000). Small high-technology firms and international hightechnology markets. Journal of International Marketing, 8(2): 63-85.

Dai, L., Maksimov, V., Gilbert, B. A., \& Fernhaber, S. A. (2014). Entrepreneurial orientation and international scope: The differential roles of innovativeness, proactiveness, and risk-taking. Journal of Business Venturing, 29(4): 511-524.

Dess, G. G., \& Robinson, R. B. (1984). Measuring organizational performance in the absence of objective measures: The case of the privately-held firm and conglomerate business unit. Strategic Management Journal, 5(3): 265-273.

Eberhard, M., \& Craig, J. (2013). The evolving role of organisational and personal networks in international market venturing. Journal of World Business, 48(3): 385-397.

Edmondson, A. C., \& McManus, S. E. (2007). Methodological fit in management field research. Academy of Management Review, 32(4): 1155-1179.

Efrat, K., \& Shoham, A. (2012). Born global firms: The differences between their shortand long-term performance drivers. Journal of World Business, 47(4): 675-685.

Egan, T. M., Yang, B., \& Bartlett, K. R. (2004). The effects of organizational learning culture and job satisfaction on motivation to transfer learning and turnover intention. Human Resource Development Quarterly, 15(3): 279-301.

Fan, T., \& Phan, P. (2007). International new ventures - Revisiting the influences behind the 'born-global' firm. Journal of International Business Studies, 38(7): 1113-1131.

Fiol, C. M., \& Lyles, M. A. (1985). Organizational learning. Academy of Management Review, 10(4): 803-813.

Francis, J., \& Collins-Dodd, C. (2000). The impact of firms' export orientation on the export performance of high-tech small and medium-sized enterprises. Journal of International Marketing, 8(3): 84-103.
Freeman, S., \& Cavusgil, S. T. (2007). Toward a typology of commitment states among managers of born-global firms: A study of accelerated internationalization. Journal of International Marketing, 15(4): 1-40.

Freeman, S., Deligonul, S., \& Cavusgil, S. T. (2013). Strategic re-structuring by bornglobals using outward and inward-oriented activity. International Marketing Review, 30(2): 156-182.

Freeman, S., Edwards, R., \& Schroder, B. (2006). How smaller born global firms use networks and alliances to overcome constraints to rapid internationalization. Journal of International Marketing, 14(3): 33-63.

Frishammar, J., \& Andersson, S. (2009). The overestimated role of strategic orientations for international performance in smaller firms. Journal of International Entrepreneurship, 7(1): 57-77.

Gabrielsson, P., Gabrielsson, M., \& Seppälä, T. (2012). Marketing strategies for foreign expansion of companies originating in small and open economies: The consequences of strategic fit and performance. Journal of International Marketing, 20(2) $25-48$.

Gassmann, O., \& Keupp, M. M. (2007). The competitive advantage of early and rapidly internationalising SMEs in the biotechnology industry: A knowledge-based view. Journal of World Business, 42(3): 350-366.

Glaser, B. G., \& Strauss, A. L. (1967). The discovery of grounded theory: Strategies for qualitative research. Chicago: Aldine Publishing Company

Grant, R. M. (1991). The resource-based theory of competitive advantage: Implications for strategy formulation. California Management Review, 33(3): 114-135.

Greene, J. C., Caracelli, V. J., \& Graham, W. F. (1989). Toward a conceptual framework for mixed-method evaluation designs. Educational Evaluation and Policy Analysis, 11(3): 255-274

Guest, G., Bunce, A., \& Johnson, A. (2004). How many interviews are enough? An experiment with data saturation and variability. Field Methods, 18(1): 59-82.

Gupta, A. K., \& Govindarajan, V. (1984). Business unit strategy, managerial characteristics, and business unit effectiveness at strategy implementation. Academy of Management Journal, 27(1): 25-41.

Hall, R. (1993). A framework linking intangible resources and capabilities to sustainable competitive advantage. Strategic Management Journal, 14(8): 607-618.

Hashai, N., \& Almor, T. (2004). Gradually internationalizing 'born global' firms: An oxymoron? International Business Review, 13(4): 465-483.

Hughes, M., \& Morgan, R. E. (2007). Deconstructing the relationship between entrepreneurial orientation and business performance at the embryonic stage of firm growth. Industrial Marketing Management, 36(5): 651-661.

Hult, G. T. M., Hurley, R. F., \& Knight, G. A. (2004). Innovativeness: Its antecedents and impact on business performance. Industrial Marketing Management, 33(5): 429438.

Hult, G. T. M., Ketchen, D. J., Jr., Griffith, D. A., Chabowski, B. R., Hamman, M. K., Dykes, B. J., et al. (2008). An assessment of the measurement of performance in international business research. Journal of International Business Studies, 39(6): 1064 1080.

Hult, G. T. M., Ketchen, D. J., Jr., \& Nichols, J. E. L. (2003). Organizational learning as a strategic resource in supply management. Journal of Operations Management, 21(5): 541-556.

Hunt, S. D., \& Morgan, R. M. (1995). The comparative advantage theory of competition. Journal of Marketing, 59(2): 1-15.

Hurmerinta-Peltomäki, L., \& Nummela, N. (2006). Mixed methods in international business research: A value-added perspective. Management International Review, 46(4): 439-459.

Jantunen, A., Nummela, N., Puumalainen, K., \& Saarenketo, S. (2008). Strategic orientations of born globals - Do they really matter? Journal of World Business, 43(2): 158 170.

Jaworski, B. J., \& Kohli, A. K. (1993). Market orientation: Antecedents and consequences. Journal of Marketing, 57(3): 53-70.

Jick, T. D. (1979). Mixing qualitative and quantitative methods: Triangulation in action. Administrative Science Quarterly, 24(4): 602-611.

Johanson, J., \& Mattson, L.-G. (1988). Internationalisation in industrial systems - A network approach. In N. Hood J.-E. Vahlne (Eds.), Strategies in global competition (pp. 287-314). New York: Croom Helm.

Johanson, J., \& Vahlne, J.-E. (1992). Management of foreign market entry. Scandinavian International Business Review, 1(3): 9-27.

Johanson, J., \& Vahlne, J.-E. (2009). The Uppsala internationalization process revisited: From liability of foreignness to liability of outsidership. Journal of International Business Studies, 40(9): 1411-1431.

Jones, M. V., Coviello, N., \& Tang, Y. K. (2011). International Entrepreneurship research (1989-2009): A domain ontology and thematic analysis. Journal of Business Venturing, 26(6): 632-659.

Jones, M. V., \& Young, S. (2009). Does entry mode matter? Reviewing current themes and perspectives. In M. V. Jones, P. Dimitratos, M. Fletcher, \& S. Young (Eds.), Internationalization, entrepreneurship and the smaller firm: Evidence from around the world (pp. 6-19). Cheltenham: Edward Elgar.

Joo, B.-K., \& Lim, T. (2009). The effects of organizational learning culture, perceived job complexity, and proactive personality on organizational commitment and intrinsic motivation. Journal of Leadership \& Organizational Studies, 16(1): 48-60.

Katsikeas, C. S., Leonidou, L. C., \& Morgan, N. A. (2000). Firm-level export performance assessment: Review, evaluation, and development. Journal of the Academy of Marketing Science, 28(4): 493-511

Keupp, M. M., \& Gassmann, O. (2009). The past and the future of international entrepreneurship: A review and suggestions for developing the field. Journal of Management, 35(3): 600-633.

Knight, G. A. (2001). Entrepreneurship and strategy in the international SME. Journal of International Management, 7(3): 155-171. 
Knight, G. A., \& Cavusgil, S. T. (1996). The born global firm: A challenge to traditional internationalization theory. In S. T. Cavusgil \& T. Madsen (Eds.), Advances in international marketing (pp. 11-26). Greenwich: JAI Press.

Knight, G. A., \& Cavusgil, S. T. (2004). Innovation, organizational capabilities, and the born-global firm. Journal of International Business Studies, 35(2): 121-141.

Knight, G. A., \& Cavusgil, S. T. (2005). A taxonomy of born global firms. Management International Review, 45(3): 15-35.

Knight, G. A., \& Kim, D. (2009). International business competence and the contemporary firm. Journal of International Business Studies, 40(2): 255-273.

Knight, G. A., Madsen, T. K., \& Servais, P. (2004). An inquiry into born-global firms in Europe and the USA. International Marketing Review, 21(6): 645-665.

Kocak, A., \& Abimbola, T. (2009). The effects of entrepreneurial marketing on born global performance. International Marketing Review, 26(4/5): 439-452.

Kohli, A. K., \& Jaworski, B. J. (1990). Market orientation: The construct, research propositions, and managerial implications. Journal of Marketing, 54(2): $1-18$.

Kropp, F., Lindsay, N. J., \& Shoham, A. (2006). Entrepreneurial, market, and learning orientations and international entrepreneurial business venture performance in South African firms. International Marketing Review, 23(5): 504-523.

Kuivalainen, O., Saarenketo, S., \& Puumalainen, K. (2012). Start-up patterns of internationalization: A framework and its application in the context of knowledgeintensive SMEs. European Management Journal, 30(4): 372-385.

Kuivalainen, O., Sundqvist, S., \& Servais, P. (2007). Firms' degree of born-globalness, international entrepreneurial orientation and export performance. Journal of World Business, 42(3): 253-267.

Kuzel, A. (1992). Sampling in qualitative inquiry. In B. Crabtree \& W. Miller (Eds.), Doing qualitative research (pp. 31-44). Newbury Park: Sage.

Larimo, J. (2006). Different types of exporting SMEs: Similarities and differences in export performance. In S. Zou (Ed.), Advances in international marketing (pp. 17-62). Bingley: Emerald.

Lee, C., Lee, K., \& Pennings, J. M. (2001). Internal capabilities, external networks, and performance: A study on technology-based ventures. Strategic Management Journal, 22(6/7): 615-640.

Liesch, P., Steen, M., Middleton, S., \& Weerawardena, J. (2007). Born to be global: A closer look at the international venturing of Australian born global firms. Sydney: Australian Business Foundation.

Lindsay, V. J. (2004). Computer-assisted qualitative data analysis: Application in an export study. In R. Marschan-Piekkari \& C. Welch (Eds.), Handbook of qualitative research methods for international business (pp. 486-506). Cheltenham: Edward Elgar.

Loane, S., \& Bell, J. (2006). Rapid internationalisation among entrepreneurial firms in Australia, Canada, Ireland and New Zealand - An extension to the network approach. International Marketing Review, 23(5): 467-485.

Lumpkin, G. T., \& Dess, G. G. (1996). Clarifying the entrepreneurial orientation construct and linking it to performance. Academy of Management Review, 21(1): 135172 .

Madsen, T. K. (1989). Successful export marketing management: Some empirical evidence. International Marketing Review, 6(4): 41-57.

Madsen, T. K. (2013). Early and rapidly internationalizing ventures: Similarities and differences between classifications based on the original international new venture and born global literatures. Journal of International Entrepreneurship, 11(1): 65-79.

Madsen, T. K., \& Servais, P. (1997). The internationalization of born globals - An evolutionary process. International Business Review, 6(6): 1-14.

Manolova, T. S., Manev, I. M., \& Gyoshev, B. S. (2010). In good company: The role of personal and inter-firm networks for new-venture internationalization in a transition economy. Journal of World Business, 45(3): 257-265.

Markman, G. D., Baron, R. A., \& Balkin, D. B. (2005). Are perseverance and self-efficacy costless? Assessing entrepreneurs' regretful thinking. Journal of Organizational Behaviour, 26(1): 1-19.

Mavrogiannis, M., Bourlakis, M. A., Dawson, P. J., \& Ness, M. R. (2008). Assessing performance in the Greek food and beverage industry - An integrated structura equation model approach. British Food Journal, 110(7): 638-654.

McAuley, A. (1999). Entrepreneurial instant exporters in the Scottish arts and crafts sector Journal of International Marketing 7(4): 67-82.

McDougall, P. P., \& Robinson, R. B. (1990). New venture strategies: An empirical identification of eight 'archetypes' of competitive strategies for entry. Strategic Management Journal, 11(6): 447-467.

McDougall, P. P., \& Oviatt, B. M. (2000). International entrepreneurship: The intersection of two research paths. Academy of Management Journal, 43(5): 902-906.

McDougall, P. P., Shane, S., \& Oviatt, B. M. (1994). Explaining the formation of international new ventures: The limits of theories from international business research. Journal of Business Venturing, 9: 467-487.

McKinsey \& Co. (1993). Emerging exporters: Australia's high value-added manufacturing exporters. Melbourne: Australian Manufacturing Council.

Menon, A., Jaworski, B. J., \& Kohli, A. K. (1997). Product quality: Impact of interdepartmental interactions. Journal of the Academy of Marketing Science, 25(3): 187-200.

Miles, M. B., \& Huberman, A. M. (1994). Qualitative data analysis: An expanded source book. Thousand Oaks: Sage.

Miller, D. (1986). Configurations of strategy and structure: Toward a synthesis Strategic Management Journal, 7(3): 233-249.

Moen, O. (2002). The born globals: A new generation of small European exporters. International Marketing Review, 19(2/3): 156-175.

Morgan, R. E., \& Strong, C. A. (2003). Business performance and dimensions of strategic orientation. Journal of Business Research, 56(3): 163-176.
Mort, G. S., \& Weerawardena, J. (2006). Networking capability and international entrepreneurship - How networks function in Australian born global firms. International Marketing Review, 23(5): 549-572.

Mudambi, R., \& Zahra, S. A. (2007). The survival of international new ventures. Journal of International Business Studies, 38(2): 333-352.

Nahapiet, J., \& Ghoshal, S. (1998). Social capital, intellectual capital, and the organizational advantage. Academy of Management Review, 23(2): 242-266.

Narver, J. C., \& Slater, S. F. (1990). The effect of a market orientation on business profitability. Journal of Marketing 54(4): 20-35.

Newbert, S. (2007). Empirical research on the resource-based view of the firm: An assessment and suggestions for future research. Strategic Management Journal, 28(2): 121-146.

North, D. (1990). Institutions, institutional change and economic performance. Cambridge: Cambridge University Press.

Nunnally, J. C. (1978). Psychometric theory. New York: McGraw-Hill.

Oviatt, B. M. \& McDougall, P. P. (1994). Toward a theory of international new ventures. Journal of International Business Studies, 25(1): 45-64.

Oviatt, B. M., \& McDougall, P. P. (2005a). Defining international entrepreneurship and modeling the speed of internationalization. Entrepreneurship Theory and Practice, 29(5): 537-554.

Oviatt, B. M., \& McDougall, P. P. (2005b). The internationalization of entrepreneurship. Journal of International Business Studies, 36(1): 2-8.

Podsakoff, P. M., MacKenzie, S. B., Lee, J.-Y., \& Podsakoff, N. P. (2003). Common method biases in behavioral research: A critical review of the literature and recommended remedies. Journal of Applied Psychology, 88(5): 879-903.

Podsakoff, P. M., \& Organ, D. W. (1986). Self-reports in organizational research: Problems and prospects. Journal of Management, 12(4): 531-544.

Porter, M. E. (1980). Competitive strategy. New York: The Free Press.

Rennie, M. W. (1993). Born global. McKinsey Quarterly, 4: 45-52.

Rialp, A., Rialp, J., \& Knight, G. A. (2005). The phenomenon of early internationalizing firms: What do we know after a decade (1993-2003) of scientific inquiry? International Business Review, 14(2): 147-166.

Ripolles, M., \& Blesa, A. (2012). International new ventures as "small multinationals": The importance of marketing capabilities. Journal of World Business, 47(2): 277 287.

Ruokonen, M., Nummela, N., Puumalainen, K., \& Saarenketo, S. (2008). Market orientation and internationalisation in small software firms. European Journal of Marketing, 42(11/12): 1294-1315.

Ruokonen, M., \& Saarenketo, S. (2009). The strategic orientations of rapidly internationalizing software companies. European Business Review, 21(1): 17-41.

Sapienza, H. J., Smith, K. G., \& Gannon, M. J. (1988). Using subjective evaluations of organizational performance in small business research. American Journal of Small Business, 12(3): 45-53.

Schwens, C., \& Kabst, R. (2008). How early internationalizers venture abroad: A review. In R. Moser (Ed.), Ausländische Direktinvestitionen: Neuere Entwicklungen, Entscheidungsinstrumente und führungsrelevante Folgen (pp. 1-19). Wiesbaden: Gabler.

Senge, P. M. (1990). The fifth discipline: The art and practice of the learning organization. New York: Doubleday Currency.

Sharma, D. D., \& Blomstermo, A. (2003). The internationalization process of born globals: A network view. International Business Review, 12(6): 739-753.

Shoham, A. (1998). Export performance: A conceptualization and empirical assessment. Journal of International Marketing, 6(3): 59-81.

Sinkovics, R. R., \& Penz, E. (2011). Multilingual elite-interviews and software-based analysis - Problems and solutions based on CAODAS. International Journal of Market Research, 53(5): 705-724.

Sinkovics, R. R., Penz, E., \& Ghauri, P. N. (2008). Enhancing the trustworthiness of qualitative research in international business. Management International Review, 48(6): 689-714

Sinkula, J. M., Baker, W. E., \& Noordewier, T. (1997). A framework for market-based organizational learning: Linking values, knowledge, and behavior. Journal of the Academy of Marketing Science, 25(4): 305-318.

Slater, S. F., \& Narver, J. C. (1995). Market orientation and the learning organization. Journal of Marketing, 59(3): 63-74.

Sleuwaegen, L., \& Onkelinx, J. (2014). International commitment, post-entry growth and survival of international new ventures. Journal of Business Venturing, 29(1): $106-120$.

Sousa, C. M. P. (2004). Export performance measurement: An evaluation of the empirical research in the literature. Academy of Marketing Science Review, 4(9): 1-22.

Sousa, C. M. P., Martinez-Lopez, F. J., \& Coelho, F. (2008). The determinants of export performance: A review of the literature between 1998 and 2005. International Journal of Management Reviews, 10(2): 1-32.

Styles, C. (1998). Export performance measures in Australia and the United Kingdom. Journal of International Marketing, 6(3): 12-36.

Teddlie, C., \& Tashakkori, A. (2003). Major issues and controversies in the use of mixed methods in the social and behavioral sciences. In A. Tashakkori \& C. Teddlie (Eds.) Handbook of mixed methods in social \& behavioral research (pp. 3-50). Thousand Oaks: Sage.

Thai, M. T. T., \& Chong, L. C. (2008). Born-global: The case of four Vietnamese SMEs. Journal of International Entrepreneurship, 6(2): 72-100.

Thirkell, P. J., \& Dau, R. (1998). Export performance: Success determinants for New Zealand manufacturing exporters. European Journal of Marketing, 32(9/10): 813-829.

Trudgen, R., \& Freeman, S. (2014). Measuring the performance of born-global firms throughout their development process: The roles of initial market selection and internationalisation speed. Management International Review. http://dx.doi.org/ $10.1007 /$ s11575-014-0210-y 
Van Gelderen, M. (2012). Perseverance strategies of enterprising individuals. International Journal of Entrepreneurial Behaviour \& Research, 18(6): 630-648.

Venkatraman, N., \& Ramanujam, V. (1986). Measurement of business performance in strategy research: A comparison of approaches. Academy of Management Review, 11(4): 801-814.

Verbeeten, F. H. M., \& Boons, A. N. A. M. (2009). Strategic priorities, performance measures and performance: An empirical analysis in Dutch firms. European Management Journal, 27(2): 113-128.

Walker, O. C., \& Ruekert, R. W. (1987). Marketing's role in the implementation of business strategies: A critical review and conceptual framework. Journal of Marketing, 51(3): 15-33.

Weerawardena, J., Mort, G. S., Liesch, P. W., \& Knight, G. (2007). Conceptualizing accelerated internationalization in the born global firm: A dynamic capabilities perspective. Journal of World Business, 42(3): 294-306.

Wernerfelt, B. (1984). A resource-based view of the firm. Strategic Management Journal, 5(2): 171-180.

Wood, R., \& Bandura, A. (1989). Social cognitive theory of organizational management. Academy of Management Review, 14(3): 361-384.

Young, S., Dimitratos, P., \& Dana, L. P. (2003). International entrepreneurship theories: What scope for international business theories? Journal of International Entrepreneurship, 1(1): 31-42.
Zahra, S. A. (2005). A theory of international new ventures: A decade of research. Journal of International Business Studies, 36(1): 20-28.

Zahra, S. A., Ireland, R. D., \& Hitt, M. (2000). International expansion by new venture firms: International diversity, mode of market entry, technological learning, and performance. Academy of Management Journal, 43(5): 925-950.

Zhang, M., Tansuhaj, P., \& McCullough, J. M. (2009). International entrepreneurial capability: The measurement and a comparison between born global firms and traditional exporters in China. Journal of International Entrepreneurship, 7(4): 292-322.

Zhou, L. Wu, W.-P. \& Luo, X (2007). Internationalization and the performance of bornglobal SMEs: The mediating role of social networks. Journal of International Business Studies, 38(4): 673-690.

Zou, H., \& Ghauri, P. N. (2010). Internationalizing by learning: The case of Chinese hightech new ventures. International Marketing Review, 27(2): 223-244.

Zou, S., Taylor, C. R., \& Osland, G. E. (1998). The EXPERF scale: A cross-nationa generalized export performance measure. Journal of International Marketing, 6(3): 37-58.

Zucchella, A., \& Palamara, G. (2006). Niche strategy and export performance. In S. Zou (Ed.), Advances in international marketing (pp. 63-87). Bingley: Emerald.

Zucchella, A., Palamara, G., \& Denicolai, S. (2007). The drivers of the early internationalization of the firm. Journal of World Business, 42(3): 268-280. 